\title{
Grapevine Leafroll: A Complex Viral Disease Affecting a High-Value Fruit Crop
}

\author{
Rayapati Naidu \\ Washington State University, Prosser \\ Adib Rowhani \\ University of California, Davis \\ Marc Fuchs \\ Cornell University, New York State Agricultural Experiment Station, Geneva \\ Deborah Golino \\ University of California, Davis \\ Giovanni P. Martelli \\ Università degli Studi di Bari "Aldo Moro" and Istituto di Virologia Vegetale del CNR, \\ UOS Bari, Bari, Italy
}

Grapevine (Vitis spp.) is one of the most widely grown fruit crops in the world. It is a deciduous woody perennial vine for which the cultivation of domesticated species began approximately 6,000 to 8,000 years ago in the Near East $(119,152)$. Today, grapes are primarily produced from cultivars of $V$. vinifera, the Eurasian grapevine; V. labrusca, the Northeastern American grapevine; Muscadinia rotundifolia (syn. Vitis rotundifolia), the Southeastern United States grapevine; V. amurensis, the most important Asian species; and several interspecific hybrids. In most grapevinegrowing areas of the world, the majority of cultivars are planted as grafted vines-consisting of a scion cultivar grafted onto a rootstock genotype - to improve survival and production with regard to increased vigor, to protect from soil-inhabiting pests such as phylloxera (Daktulosphaira vitifoliae) and nematodes, and to promote early ripening. In regions where phylloxera is absent, grapevines can be grown as own-rooted plants.

Grapes are used for the production of fresh fruits, wines, juices, raisins, and in several byproducts such as jellies, vinegars, and seed oils. In 2010, 7.19 million hectares were dedicated worldwide to the production of about 68 million metric tons (53). The four top grape producing countries in 2010 were the People's Republic of China (8.65 million metric tons), Italy ( 7.7 million metric tons), the United States (6.2 million metric tons), and Spain (6.1 million metric tons) (53). In the United States, the grape, wine, and juice industries are important and fast-growing segments of the economy with commercial operations present in nearly every state in the country. The total crop value was $\$ 3.47$ billion in 2010 , with California accounting for $\$ 3.0$ billion (87\%) followed by Washington ( $\$ 214$ million or approximately 6\%) and New York (\$68.4 million or approximately 2\%) (124). Approximately $58 \%$ of the grape production in the United States is used for wines, $23 \%$ for raisins, $13.5 \%$ for fresh fruits, $5.2 \%$ for juice, and $0.3 \%$ for canned products (124). A recent impact study revealed that the grape and wine industry has become an economic catalyst contributing more than $\$ 162$ billion annually to the American economy (117).

Corresponding author: Rayapati Naidu, Department of Plant Pathology, Irrigated Agriculture Research and Extension Center, Washington State University, Prosser, WA 99350 USA; E-mail: naidu.rayapati@wsu.edu

http://dx.doi.org/10.1094/PDIS-08-13-0880-FE

(C) 2014 The American Phytopathological Society
Grapevines are broadly classified into red- and white-berried cultivars based on their fruit skin color, although yellow, pink, crimson, dark blue, and black-berried cultivars also exist. Redberried cultivars have anthocyanin pigments in berry skin, whereas white-fruited cultivars lack this pigment since regulatory genes of the anthocyanin biosynthetic pathway are nonfunctional in these cultivars (162).

Grapevines can be subject to attacks by many different pests and pathogens, including graft-transmissible agents such as viruses, viroids, and phytoplasmas (109). Currently, more than 60 different viruses belonging to nearly 30 different genera have been documented in grapevines $(108,126)$. On a worldwide basis, more viruses have been identified in grapevines than in any other woody perennial crop. All currently documented grapevine viruses are classified into four major groups based on the disease they cause or are associated with: viruses involved in the degeneration/decline disease complex, viruses associated with the leafroll disease complex, viruses associated with the rugose wood complex, and viruses associated with the fleck disease complex. Other grapevine viruses are apparently not associated with a disease and are suspected to have a minor, if any, impact $(107,109,126)$. The majority of grapevine viruses have a RNA genome. Recently, two viruses with a DNA genome have been reported: a badnavirus associated with vein-clearing and vine decline syndrome (169), and a geminivirus associated with red blotch symptoms $(8,92,133)$, with the latter emerging as an economically important constraint to grape production in the United States.

Among the virus and virus-like diseases, grapevine leafroll disease (GLD) is by far the most widespread and economically damaging viral disease of grapevines in many regions around the world $(57,107,121,125)$. A recent economic study indicated that GLD, depending on the level of disease incidence, yield reduction, and impact on fruit quality, can cause an estimated loss of approximately $\$ 25,000$ to $\$ 40,000$ per hectare in the absence of any control measure (10). GLD was described in Europe as early as the mid-nineteenth century (107) and then in many other countries throughout the world, including in the United States $(63,81,82)$. The graft-transmissibility of GLD was demonstrated in 1935 (144), and the presence of flexuous, filamentous virus particles was reported in a leafroll-affected grapevine in 1979 (123). A decade later, the ability of mealybugs to transmit one of the viruses associated with GLD was demonstrated $(137,151)$. As improved diagnostic techniques became available, several viruses associated with GLD were characterized during the last three decades. These vi- 
ruses are collectively referred to as Grapevine leafroll-associated viruses or GLRaVs $(110,111)$.

The global expansion of the grape and wine industry has seen a parallel increase in the incidence and economic impact of GLD. Despite the fact that GLD was recognized as a potential threat to grape production for several decades, our knowledge of the nature of the disease is still quite limited due to a variety of challenges related to the complexity of this virus disease, the association of several genetically and serologically distinct GLRaVs, and contrasting symptoms in red- and white-berried cultivars. In view of the growing significance of GLD to wine grape production worldwide, this feature article provides an overview of the state of knowledge on the biology and epidemiology of the disease and describes management strategies currently deployed in vineyards.

\section{Symptoms}

Only cultivars of European grapevines (viz. V. vinifera) and some Asian Vitis species (viz. V. coignetiae; 142) exhibit conspicuous symptoms of the disease. In contrast, $V$. californica and natural $V$. californica $\times V$. vinifera hybrids (88), juice grapes (viz. V. labruscana 'Concord' and V. labrusca 'Niagara'), muscadine grapes (M. rotundifolia), and rootstocks (viz. V. riparia, V. rupestris, $V$. berlandieri, $V$. champini, and crosses thereof) are asymptomatic hosts. In V. vinifera, GLD produces contrasting symptoms on the foliage in red- and white-berried cultivars (Fig. 1; 64,106,121,165). In many red-berried cultivars, symptomatic leaves exhibit red or reddish-purple discolorations in inter-veinal areas, but a narrow strip of leaf tissue on either side of the main veins remains green, giving the appearance of "green veins" (Fig. 1A). The red and reddish-purple coloration of symptomatic leaves is due to the accumulation of specific classes of anthocyanin pigments (75). In contrast, white-berried cultivars show mild yellowing or chlorotic mottling of inter-veinal areas of leaves (Fig. 1C). These symptoms, however, are often subtle and may not be recognized in many white-berried cultivars. In both red- and white-berried cultivars, symptoms often appear first on mature leaves at the bottom portion of the canopy around véraison (a transitional phase representing the onset of berry ripening with change of berry skin color [35]) and progressively move upward to younger leaves as the season advances. In general, GLD symptoms become apparent in early to mid-summer, and symptomatic leaves of both types of cultivars usually show downward rolling of leaf margins toward the end of the season (Fig. 1B and D), giving the name leafroll disease $(109,121)$.

It should be noted, however, that the extent of foliar symptoms and downward rolling of leaves varies considerably among cultivars. Some red-berried $V$. vinifera cultivars such as Pinot noir and Cabernet franc, and white-berried $V$. vinifera cultivars such as Chardonnay show pronounced downward rolling of leaves by harvest time. In other cultivars, downward rolling of leaf margins may not be apparent at all. As a result, visual diagnosis of GLD symptoms is difficult in the latter cultivars. In addition, expression of disease symptoms can be influenced by cultivar, scion-rootstock combination, and environmental factors prevailing in a given grapevine-growing region. In the case of red-berried $V$. vinifera cultivars, nutritional disorders (such as potassium deficiency), mechanical damage to the trunk inflicted during viticultural operations or wind abrasion between canes, and girdling of leaves by tendrils and shoots by buffalo leafhopper (Ceresa bubalus) oviposition and red blotch disease can produce discolorations that mimic GLD symptoms.

From the above discussion, it should be emphasized that GLD symptoms are highly variable between cultivars and even within the same cultivar. In addition, some strains of both GLRaV-2 and -7 can cause asymptomatic infections in certain wine grape cultivars $(9,16,86,134)$. Thus, testing suspect samples for GLRaVs
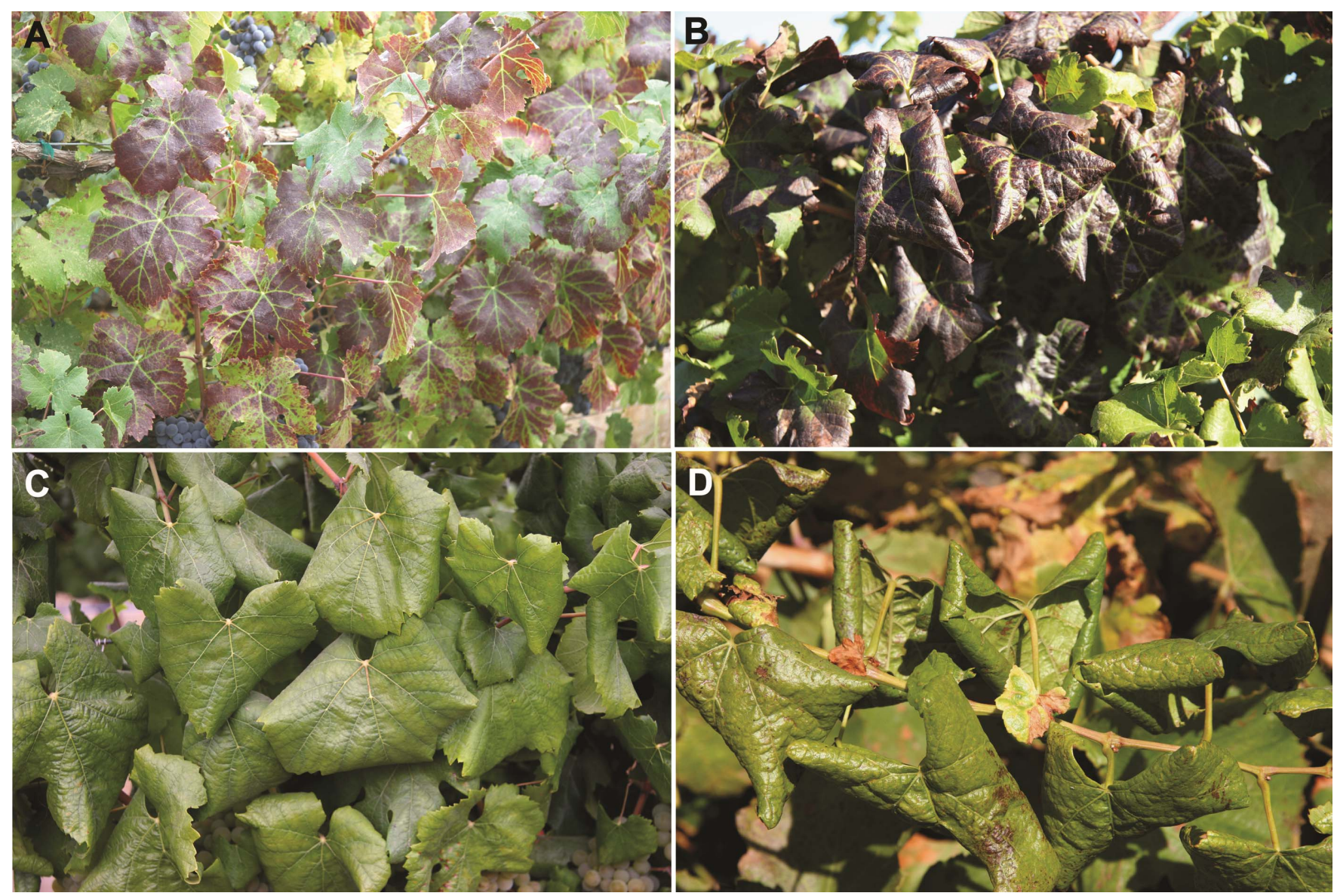

Fig. 1. Foliar symptoms of grapevine leafroll disease in ( $A$ and $B)$ red- and (C and $D)$ white-berried wine grape cultivars. Downward rolling of leaf margins (B and $D)$ is commonly visible in both types of cultivars toward the later part of the season. $A$ and $B=$ Merlot, $C$ and $D=C$ Chardonnay. 
using sensitive diagnostic methods described below is a vital step in determining the viral nature of symptoms and for making appropriate disease management recommendations to growers.

\section{Viruses Associated with GLD}

GLRaVs are morphologically similar but serologically and genetically distinct viruses. They are numbered serially as GLRaV-1, $-2,-3,-4$, and so on (110), and belong to the plant virus family Closteroviridae $(87,110,111)$. GLRaV virions are flexuous rods, with lengths ranging between 1,400 and 2,200 nm and a diameter of about $12 \mathrm{~nm}$. They encapsidate a linear, positive-sense, singlestranded RNA genome with a possible cap structure at the $5^{\prime}$ terminus and no poly(A) track at the $3^{\prime}$ terminus. Similar to other closteroviruses (87), the genomic RNA of GLRaVs may constitute about $5 \%$ of the total mass of virions. Like other members of the family Closteroviridae, GLRaVs may have bipolar virions with most of the genome encapsidated by the coat protein (CP) and the $5^{\prime}$ extremity of virions having a segmented "tail" structure made up of several other virus-encoded proteins $(130,143)$. It has been hypothesized that the segmented tail of a closterovirus functions as a movement device guiding directional transport of viral genomes between neighboring cells (46). Likewise, the segmented tails of GLRaVs may have similar functions. Based on the current understanding of the functional roles of proteins encoded by Beet yellows virus (45) and Citrus trizteza virus (44), proteins encoded by GLRaVs could be multifunctional, involved in various aspects of the virus life cycle. GLRaVs are limited to phloem-associated cells, replicate in companion and phloem parenchyma cells, and can affect the cytology of differentiating sieve tubes, parenchyma, and companion cells $(27,54)$, a characteristic of plant infection by members of the family Closteroviridae (170).

In general, GLRaVs are unevenly distributed in grapevines and exist in low concentrations (157). They are usually present in an infected grapevine as mixed infections of several GLRaVs or GLRaVs with other viruses. Mixed infections may have resulted from the continual vegetative propagation of grapevines over many centuries and grafting between different scion and rootstock materials $(58,120,136)$. Such mixed infection of GLRaVs may lead to either synergistic or antagonistic interactions, commonly observed between plant viruses co-infecting the same host (150). Among the currently known GLRaVs, GLRaV-3 appears to be the most widespread, as single or mixed infections with other GLRaVs, grapevine viruses and viroids, in areas where GLD is present $(28,105)$.

\section{Taxonomy, Genome Organization, and Diversity of GLRaVs}

GLRaVs belong to distinct genera in the family Closteroviridae (Fig. 2; 110,111). GLRaV-1, -3 , and -4 are assigned to the genus Ampelovirus (derived from ampelos, meaning grapevine in Greek) with GLRaV-3 as the type species, whereas GLRaV-2 belongs to the genus Closterovirus (from kloster, meaning thread in Greek) typified by Beet yellows virus. GLRaV-7 is assigned to the newly proposed genus Velarivirus (from velari, meaning cryptic in Latin) (9). Recent taxonomic revisions have designated GLRaV-5, -6, -9, GLRaV-Pr, GLRaV-De, and GLRaV-Car as genetically divergent strains of GLRaV-4 due to similarity in their overall genome size and genetic organization. Consequently, these former virus species are now grouped under the umbrella term "GLRaV-4-like" viruses (110).

At present, the full-length genome sequence of almost all known GLRaVs is available in public databases. GLRaVs are genetically diverse with open reading frames (ORFs) encoded by each virus varying in size and number (Fig. 3). Current sequence data indicate that GLRaV-4 strain 'Car' is the smallest of the GLRaVs with 13,626 nucleotides (nt) encoding six ORFs (1), and GLRaV-3 is the largest and the most complex with 18,671 nt encoding 12 ORFs $(55,85,105)$. Although the genome organization of GLRaVs has similarities to the gene modules characteristic of closterovirids, some differences are notable and appear to be unique to viruses associated with GLD. Similar to members of the genus Closterovirus (46), all GLRaVs have a signature replication gene block (RGB) that covers a large portion of the genome toward the $5^{\prime}$ terminus. The RGB is made up of replication-associated proteins encoded by ORFs $1 \mathrm{a}$ and $1 \mathrm{~b}$. The polymerase module encoded by ORF1a is made up of domains for one or two papain-like leader proteases, methyl transferase- and helicase-like domains with large inter-domain region. Unlike other GLRaVs, the ORF1a of GLRaV3 and GLRaV-4 and its strains contains an AlkB domain within the large inter-domain region $(2,105,110,154)$. In all GLRaVs, ORF1b expresses the RNA-dependent RNA polymerase-like domain via a +1 frameshift translation. The other ORFs are located downstream of RGB toward the $3^{\prime}$ terminus of the genome. A signature quintuple gene module, consisting of a 6-kDa protein (p6 or its homologue), a heat-shock protein 70 homolog (HSP70h), a $\sim 60-\mathrm{kDa}$ protein (p55 or its homologue), the $\mathrm{CP}$ and a minor $\mathrm{CP}(\mathrm{CPm})$, is present in GLRaV-1, -2 , and -3 , but not in GLRaV-4 and its strains $-5,-6,-9,-P r$, -De, and -Car, and GLRaV-7. As expected, the arrangement of $\mathrm{CP}$ and $\mathrm{CPm}$ in GLRaV-2 is similar to that in members of the genus Closterovirus. In contrast, GLRaV-1, -3 , and -7 genomes have $\mathrm{CP}$ and $\mathrm{CPm}$ ORFs in the reverse order relative to GLRaV-2. Further, GLRaV-1 shows an additional peculiarity in that its genome has two divergent copies of $\mathrm{CPm}$. In contrast, $\mathrm{CPm}$ is absent in GLRaV-4 and its strains -5, -6, -9, -Pr, -De, and -Car. Thus, it is clear that all characterized GLRaVs show remarkable differences in number and arrangement of ORFs that appear to be characteristic of each virus species. Based on the genome size, gene organization, and genetic variability, GLRaVs in the genus Ampelovirus have been divided into two subgroups, with GLRaV-1 and -3 in subgroup I, and GLRaV-4 and it strains $-5,-6,-9$, - Pr, -De, and -Car in subgroup II $(1,2,103,110,154)$.

Studies on genetic diversity of GLRaV-1, -2 , and -3 have indicated the presence of genetically diverse but closely related variants in several grapevine-growing regions $(3,20,30,70,84,146,160)$. In the case of GLRaV-3, the presence of seven possible variant groups has been reported in different cultivars and vineyards worldwide based on phylogenetic analysis of full-length CP gene sequences (105). Further, a pairwise comparison of the full-length genome of several GLRaV-3 isolates indicated an uneven distribution of sequence variation along the virus genome (105). An analysis of natural populations of GLRaV-1 and -2 from California, Washington, and New York, based on the partial HSP70h and CP gene sequences, revealed the existence of genetic variants that segregate into phylogenetically distinct groups (three in the case of GLRaV-1 and six in the case of GLRaV-2) independent of their geographic origin $(3,84)$. Since grapevines are clonally propagated and no resistance is known in Vitis spp. $(95,126)$, variants of GLRaVs could be perpetuated without being subjected to stringent purifying selection or bottleneck events. The intrinsically errorprone nature of the viral RNA-dependent RNA polymerase (149) further contributes to global genetic variability of GLRaVs leading to accumulation of genetically diverse but closely related variants of each virus, often termed "quasi-species" (47). Consequently, an individual grapevine may harbor a myriad of variants whose evolutionary dynamics can be influenced by host- and vector-imposed bottleneck events. More specifically, the genetic diversity and fitness of genetic variants among ampeloviruses (GLRaV-1, -3 , and -4 and its strains) can be influenced to a greater extent by constraints imposed by horizontal vector-mediated transmissions in comparison to GLRaV-2 and GLRaV-7, which are not yet known to be transmitted by vectors.

\section{Impact of GLD}

GLD can cause reduced plant vigor and longevity, and significant losses in both fruit yield and quality. Crop losses between 14 and $40 \%$ due to GLD infection have been reported $(62,167,168)$. The magnitude of yield losses appears to be dependent on cultivarrootstock combinations, age of vines when infection occurs, causal virus(es), single or mixed virus infection, and environmental condi- 
tions $(12,26,74,89,90,167)$. GLD is also reported to affect photosynthesis in some red-berried cultivars under field conditions $(15,36)$ as well as modulation of host genes involved in a wide spectrum of biological functions $(51,52)$.

Reduced cluster size, loose clusters, and small berries are commonly observed in GLD-affected vines (Fig. 4). One of the major impacts of GLD in red-fruited $V$. vinifera cultivars is asynchronous fruit ripening and poor color development of berries $(4,69$, 140,161), altered fruit maturity indices (soluble solids or ${ }^{\circ}$ Brix, titratable acidity or TA, and $\mathrm{pH}$ ), and modifications of individual and total anthocyanins, total phenolics, as well as total tannins $(4,69,96,97,104,161,167)$.

\section{Diagnosis}

Visual observation of GLD symptoms in affected vines is largely unreliable for consistent diagnosis of the disease under vineyard conditions. This is largely due to the highly variable nature of GLD symptoms (Fig. 1). Foliar symptoms of GLD are apparent only during late summer and fall, but not in spring. Some abiotic and biotic stresses described earlier can mimic foliar GLD symptoms, especially in red-fruited $V$. vinifera cultivars. The lack of obvious symptoms in white-fruited cultivars, latent infection in American Vitis species, interspecific hybrids, and rootstocks further complicates symptom-based diagnosis of GLD in vineyards. With improved understanding of intricacies associated with field-based

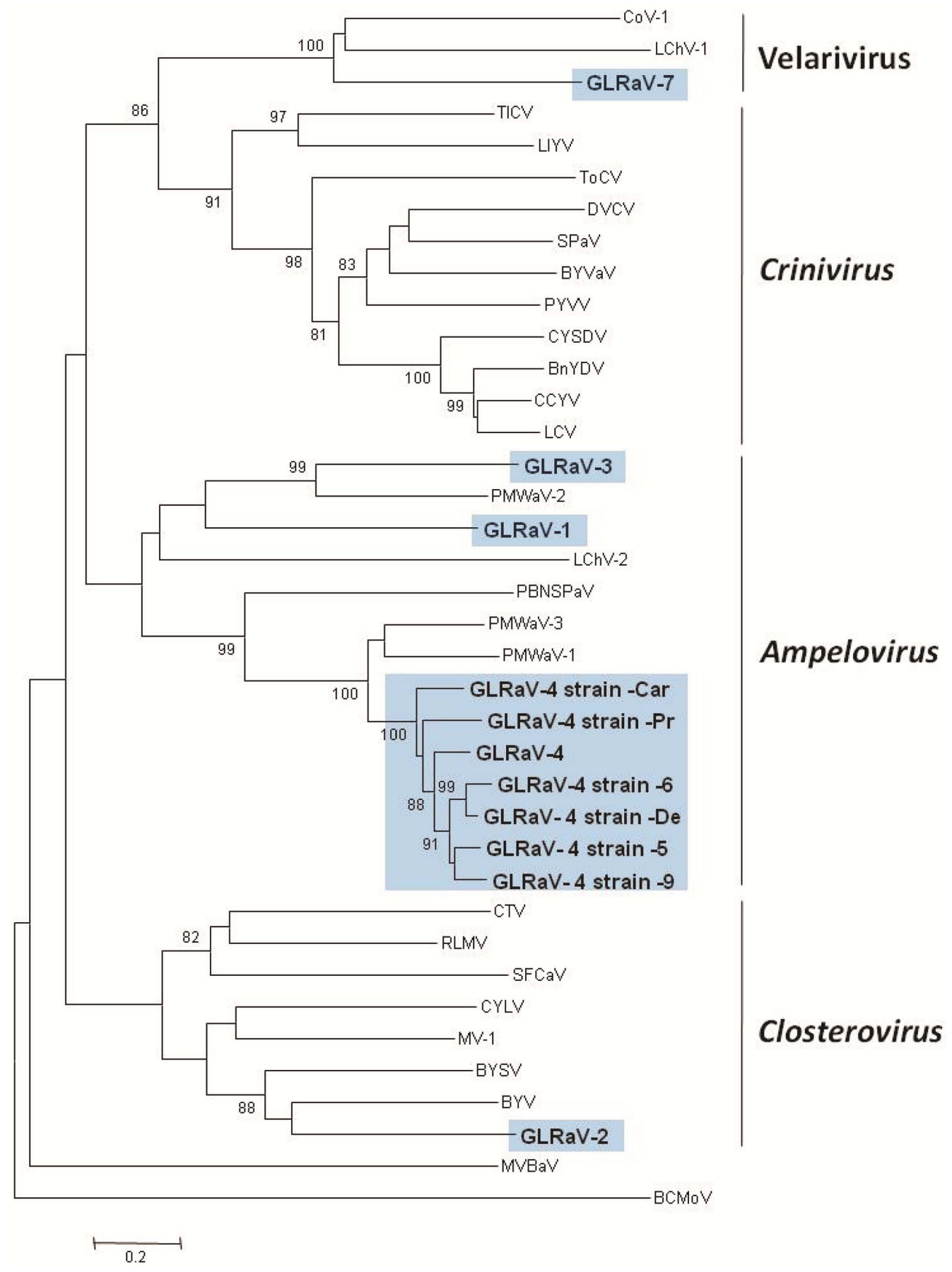

Fig. 2. Phylogenetic analysis of the coat protein (CP) gene sequence of Grapevine leafroll-associated viruses (GLRaVs) in the family Closteroviridae. The majority of GLRaVs belong to the genus Ampelovirus. Bootstrap values less than $70 \%$ are not shown. The CP gene sequence of Bean calico mosaic virus (BCMoV, NC 003504 ) was used as an outgroup. Accession numbers of GLRaVs used in this figure are: GLRaV-1 = AF195822; GLRaV-2 = AF039204; GLRaV-3 = NC004667; GLRaV-4 = FJ467503; GLRaV-4 strain -5 = FR822696; GLRaV-4 strain -6 = FJ467504; GLRaV-4 strain -9 = AY297819; GLRaV-4 strain -Car = FJ907331; GLRaV-4 strain -De = AM494935; GLRaV4 strain -PR = NC_011702; GLRaV-7 = JN383343. Figure modified from Al Rwahnih et al. (9) with permission of the publishers and the corresponding author (A. Rowhani). 
diagnosis and the nature of GLRaVs, methodologies for the specific and accurate detection of individual GLRaVs have evolved through the years to include highly sophisticated and sensitive detection techniques that can target individual GLRaVs and their molecular variants. Diagnostic methods include biological indexing using woody indicator hosts, serological assays (enzyme-linked immunosorbent assay [ELISA]), and molecular methods (reverse transcription-polymerase chain reaction [RT-PCR] and PCR) and recent approaches such as micro- and macro-arrays as well as nextgeneration sequencing (NGS), as described below.

Biological indexing. Biological indexing has been used as an important and fundamental assay for the diagnosis of GLD. It is also a standard method for establishing graft transmissibility of GLRaVs and other graft-transmissible pathogens associated with a disease, and further characterization of hitherto unknown/uncharacterized agents. Biological indexing for GLD is routinely used in clean plant programs.

In biological indexing, budwood from a candidate vine suspected of GLD infection is grafted onto an indicator plant by chip-, bench-, or micro-grafting, and the grafted plant is observed for symptoms over 2 to 3 years in a field setting (141). V. vinifera 'Cabernet franc' is a common diagnostic indicator for GLD. Other indicators used for GLD indexing are cultivars Pinot noir, Mission, Cabernet Sauvignon, and Barbera. Selection of a specific cultivar as an indicator host depends upon personal preferences of people performing indexing and on climatic conditions under which indicator plants are grown. On Cabernet franc, symptoms are interveinal reddening of the leaf blade, beginning in late summer and intensifying thereafter, with prominently green primary veins and downward rolling of leaf margins. Because GLRaVs and their strains may produce similar symptoms on Cabernet franc, it is impossible to identify a specific virus present in a candidate vine through biological indexing. Furthermore, the asymptomatic nature of some strains of both GLRaV-2 $(5,16,134)$ and GLRaV-7 $(9,86)$ limits the reliability of biological indexing. In addition, biological indexing is influenced by various factors including the efficient spread of virus(es) from the budwood piece to the recipient indicator host and climatic conditions under which field indexing is performed (34). Thus, biological indexing is not always reliable. It is also labor-intensive, requires large field or greenhouse space to grow grafted vines, and takes 2 to 3 years for vines to grow and express disease symptoms in a field setting.

Serological assays. The most common serological method used for rapid detection of GLRaVs is ELISA. This technique is based on the recognition of virus antigens with immunoglobulins or monoclonal antibodies produced against purified virions or the virus CP expressed in Escherichia coli cells. Serological reagents are commercially available and routinely used in ELISA for the detection of GLRaV-1, -2, -3, -4 , and -7 in grapevine tissue $(18,56,138)$. ELISA is sensitive, reliable, and adapted to high throughput applications for testing large numbers of samples. However, ELISA-based diagnosis of GLRaVs has some limitations and can be influenced by various factors (166). These factors include sensitivity (when a virus is present at extremely low concentrations), specificity (presence of variants of GLRaVs that may not be recognized by available antibodies), and quality of antibodies. Nevertheless, ELISA remains a reliable diagnostic tool in largescale surveys for GLD and for research purposes.

Molecular assays. Over the past two decades, diagnosis of GLRaVs using molecular assays has rapidly advanced such that a broad range of techniques is available for a more reliable detection. RT-PCR-based technologies have increased sensitivity compared to ELISA $(33,100,139)$. RT-PCR is estimated to be 100 to 1,000 times more sensitive than ELISA (139). In recent years, real-time

\section{Replication gene block Quintuple gene block}

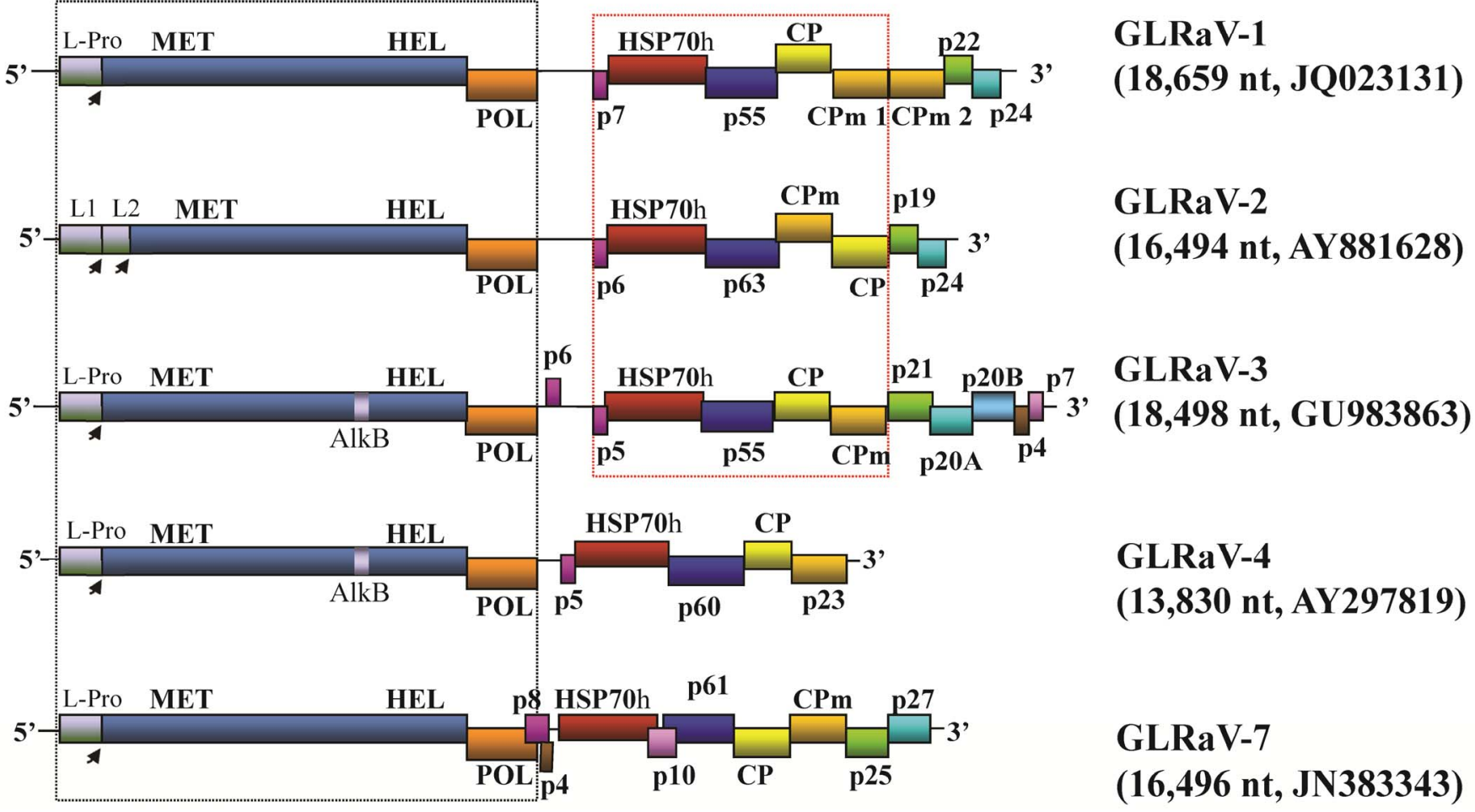

Fig. 3. Genome maps of select Grapevine leafroll-associated viruses (GLRaVs). Names of viruses, their genome size, and GenBank accession numbers are shown on the right side. The open reading frames (ORFs) are shown as boxes with associated protein designations. L-Pro, papain-like leader protease; AlkB, AlkB domain; MET, HEL, and POL, methyltransferase, RNA helicase, and RNA dependent RNA polymerase domains of the replicase, respectively; HSP70h, a HSP70-homologue; CP, the major capsid protein; CPm, the minor capsid protein. The other ORFs are designated with approximate molecular weight and a common "p" designator (46,110). Note that the $3^{\prime}$-most ORF of GLRaV-4 and its strains is not a CPm, it is denoted as p23. Unlike other GLRaVs, GLRaV-2 encodes two papain-like leader proteases, designated in the map as L1 and L2. Black box shows replication gene block encoded by all GLRaVs, and red box indicates quintuple gene block proteins encoded by GLRaV-1, -2, and -3. Figures are not drawn to scale. 
PCR, using detection chemistries such as TaqMan, is increasingly being used for the detection and quantification of GLRaVs in plant tissue and insect vectors compared to conventional RT-PCR assays (127). Low-density PCR arrays (LDA) using the real-time TaqMan PCR primers/probes complexes in 384-well plates were developed for the simultaneous detection and quantification of different GLRaVs (128). Overall, the TaqMan-based real time RT-PCR and LDA detection methods are rapid and quantitative, and can provide the required robustness in processing a large number of samples for the detection of GLRaVs (129). RT-PCR in combination with high-resolution melting curve analysis has been used for monitoring the incidence of GLRaVs and their variants in vineyards $(19,135)$. Recently, a RT loop-mediated isothermal amplification assay was developed for the rapid detection of GLRaV-3 (163). Microarray- (50) and macroarray- (153) based detection methods have been developed for the multiplex detection of GLRaVs. Although these methods are useful due to their relative simplicity and robustness, limitations include time, expertise, and costs in running the assay. One of the more exciting diagnostic developments in recent years is the application of NGS for mining sequences of viruses and virus strains in grapevines in an unbiased manner $(7,8,32,61,133,169)$. Although NGS is relatively expensive for use as a routine tool in virus diagnostics, the information generated from this emerging technology can be effectively used in molecular diagnostics for reliable and sensitive identification of viruses.

To summarize, ELISA and RT-PCR are routinely used in a complementary manner for the detection of GLRaVs. Irrespective of the method used, although molecular assays may be more sensitive than serological assays, it should be remembered that reliable detection by either of the methods depends on sampling strategy and proper controls $(118,157)$. Sampling appropriate tissue at the optimal time is one of the most critical factors influencing reliable detection of GLRaVs due to their localization in phloem-associated tissue, low concentration, and uneven distribution in infected vines. In general, petiole samples collected during late summer and fall, and cambial scrapings obtained from dormant woody canes in winter, are used for GLRaVs testing by ELISA or RT-PCR (166).

\section{Dissemination of GLRaVs}

Propagation material. Grapevines are vegetatively propagated to maintain clonal integrity and trueness-to-type, and planted as either own-rooted or grafted vines. Because of this propagation practice, GLRaVs can spread from one location to another when cuttings derived from infected vines are used for propagation $(106,107)$. This means that GLRaVs can be disseminated along with scion and/or rootstock materials used for propagation, grafting, or planting new vineyards. Dissemination of GLRaVs via these practices can happen with both red- and white-berried $V$. vinifera cultivars, native American Vitis species, as well as interspecific hybrids and rootstocks. Therefore, the use of infected cuttings or budwood for propagation, bench grafting, chip budding, and top working provide many avenues for the introduction of GLRaVs into vineyards. Because GLRaVs are not mechanically transmissible between grapevines, their spread in vineyards via pruning shears, trimmers, thinners, harvesters, or saws does not occur.

Insect vectors. Plant-to-plant dissemination of GLRaVs in the genus Ampelovirus occurs via mealybug (Pseudococcidae) and scale insect (Coccidae) vectors. Several species of mealybugs belonging to the genera Heliococcus, Phenacoccus, Planococcus, and Pseudococcus and scale insects belonging to the genera Pulvinaria, Neopulvinaria, and Parthenolecanium have been identified as vectors of GLRaV-1, -3 , and -4 and its strains (Table 1). There are no known insect vectors for GLRaV-2 and -7. Despite the fact that several members of the genus Closterovirus are transmitted by different species of aphids $(87,111)$, there is no evidence so far for transmission of GLRaV-2 by aphids under experimental or natural conditions. Aphids are not common pests of grapevine, although the grapevine aphid (Aphis illinoisensis) has been reported in several grapevine-growing areas $(80,159)$. However, current evidence indicates that A. illinoisensis is unlikely to serve as a vector for GLRaV-2. Nevertheless, GLRaV-2 can be mechanically transmitted with some difficulty from grapevine tissue to Nicotiana benthamiana (71). Recently, GLRaV-7 was demonstrated to be transmitted experimentally by the parasitic dodder Cuscuta reflexa to Tetragonia expansa and Cuscuta europea to Nicotiana occidentalis (113).

Most of the information on transmission of ampeloviruses is obtained with mealybugs rather than scale insects. Hence, the following discussion pertains to our current knowledge of ampelovirus transmission by mealybug vector species. Mealybugs show genderspecific distinction in their ability to transmit ampeloviruses. Male mealybugs are winged and capable of flight, but have only vestigial mouthparts not suitable for feeding and acquiring virus (37). Female mealybugs have functional mouthparts allowing acquisition of virus while ingesting plant sap from phloem, and subsequent transmission. However, females are wingless and are largely seden-
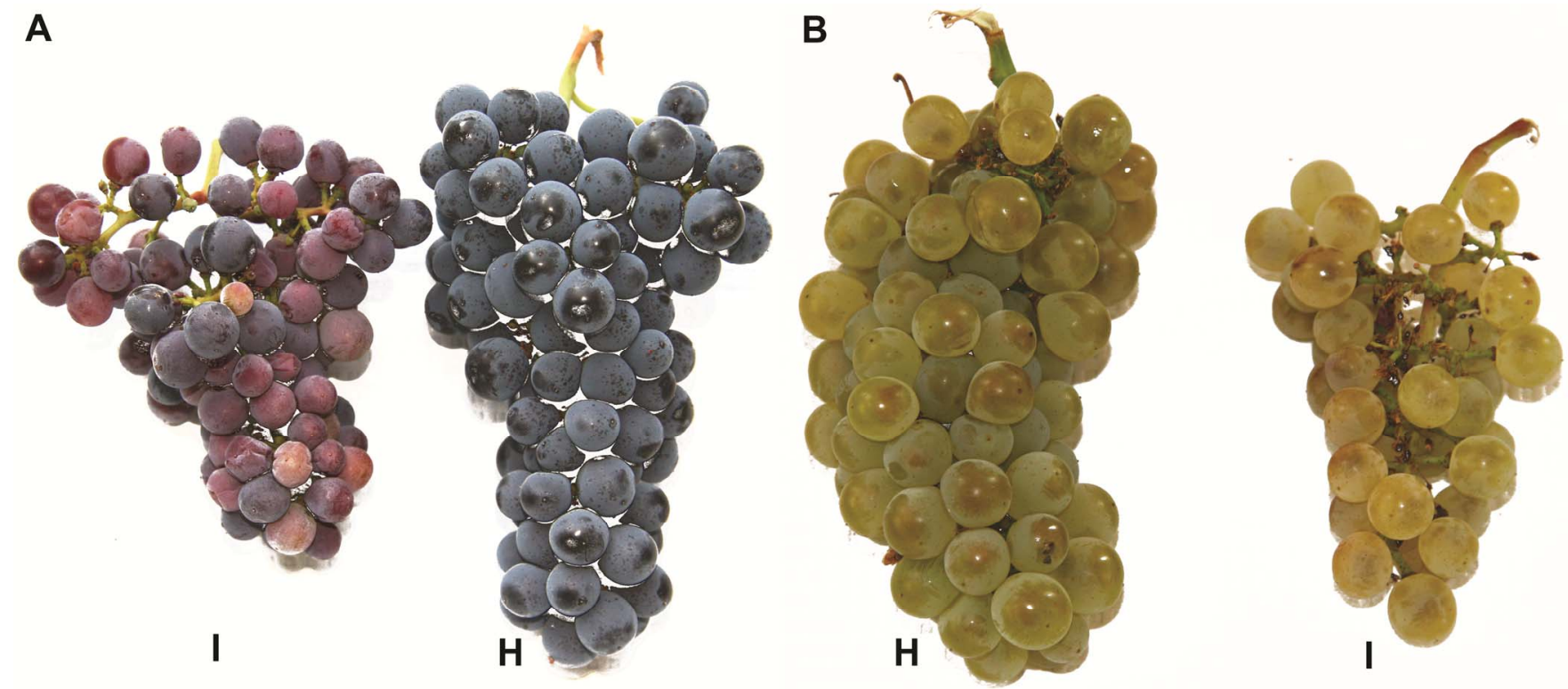

Fig. 4. Clusters produced by grapevine leafroll disease-affected vines are smaller and less compact, with berries showing uneven size and ripening. A, Red-berried Vitis vinifera cultivar (Cabernet franc), and B, white-berried cultivar (Chardonnay). $\mathrm{H}=$ Cluster from healthy vine, $\mathrm{I}=$ Cluster from infected vine. 
tary, limiting movement and spread of virus to short distances covered by crawling between immediately adjacent vines within a row and between neighboring rows (72). As a consequence of this limited mobility, the spread of GLD within a vineyard is slow unless the insect is dispersed by other means, such as human activities, or being blown by the wind or transported by foraging birds. Despite the limited mobility of mealybugs, they can be dispersed relatively long distances on wind-blown infested leaves, carried on vineyard workers' clothing, or spread by harvesting equipment carrying leaf or bark material infested with mealybugs. The first-instar nymphs or crawlers are well adapted to dispersal, whereas the later life stages and adult females are relatively immobile and make little contribution to distant spread of GLD. Although all life stages of mealybug vectors are capable of transmission, first-instar nymphs appear to be more efficient in transmission and thus play a more significant role compared to other developmental stages in the epidemiology of GLD $(131,156)$.

Studies on mealybug transmission suggest that transmission is semi-persistent (158). GLRaV-3 can be transmitted by different mealybug species and, conversely, a single mealybug species (e.g., Planococcus ficus) is capable of transmitting different ampeloviruses. This would suggest a lack of virus-vector specificity of transmission between different species of mealybug vectors and ampeloviruses $(98,158)$. Detection of GLRaV-3 in salivary glands of Planococcus citri suggests a circulative mechanism of transmission (31), in disagreement with the previous conclusions $(87,110)$. Based on studies with GLRaV-3 transmission by $P l$. ficus, acquisition and inoculation of the virus can occur within a 1hour plant access period with a transmission efficiency of ca. $10 \%$ per individual per day under greenhouse conditions (156). However, higher transmission rates were obtained with first- and possibly second-instar nymphs than with adults of $P l$. ficus and Pseudococcus longispinus $(48,131)$. A single viruliferous mealybug nymph is capable of infecting a healthy vine with GLRaV-3 (48), although variation in transmission efficiency of ampeloviruses among different mealybug species is possible (158). Source tissue, virus titer, spatial distribution of virus, and seasonal variations can also influence transmission of GLRaV-3 $(155,157)$.

A few studies have shown differences in transmission efficiency of ampeloviruses, with GLRaV-3 transmitted at higher rate than GLRaV-4 strain -5 by Pl. ficus and Ps. longispinus $(65,102)$. Also, $P l$. ficus transmitted GLRaV-4 and its strain -9, but Ps. longispinus transmitted strain -9 but not GLRaV-4 (158). Thus, in-depth research is needed to elucidate virus-vector interactions and factors influencing the relative transmission efficiency of ampeloviruses by different mealybug vector species for a better understanding of the transmission biology of ampeloviruses.
Vineyard spread of ampeloviruses. An understanding of ampelovirus spread in vineyards is essential for developing effective control measures. Primary spread or introduction of GLRaVs into a newly planted vineyard can occur either via planting virus-infected vines or be initiated by alighting viruliferous vectors. Either of these modes generally results in a random spatial distribution of infected grapevines in a vineyard. As mentioned above, it should be noted that planting infected vines results in primary spread of all GLRaVs, and viruliferous vectors can contribute to the primary spread of only ampeloviruses. Consequently, grapevines infected with GLRaV-1, -3 , and -4 and its strains can serve as an initial source for secondary spread within a vineyard by mealybug or scale insect vectors. In contrast, the secondary spread of GLRaV-2 and -7 is unlikely to occur due to the absence of insect vectors known to spread these viruses.

Several studies on the secondary spread of GLRaV-3 involving transmission by different mealybug vector species were conducted $(23-25,28,68,77,78)$. In general, the spatio-temporal spread dynamics over multiple years indicates two common patterns of secondary spread $(28,148)$. One is aggregation or clustering of infected vines, suggestive of virus spread between adjacent vines within a row and across adjacent rows as a consequence of vine-tovine movement of mealybugs around the primary foci of infection. These random patches of infection expand with time, often involving many seasons, and ultimately coalesce to cover the entire vineyard. The second common pattern of secondary spread is "edge effects" contributed mainly by incoming viruliferous vectors from sources of infection either far from or near the newly planted vineyard. Such an infection pattern results in disease gradients with a high percentage of symptomatic vines in rows alongside nearby sources of infection and a gradually decreasing incidence of the disease with increasing distance from the source of infection. Such a pattern is an indication that ampeloviruses initially spread into a newly planted vineyard from heavily infected neighboring vineyards and then secondarily inside the newly infected vineyard. These patterns of virus spread appear to be similar across grapevine-growing regions, irrespective of the vector species present in a given region.

Within-field spread of GLRaV-3 can occur even at low vector population densities, and few insects feeding on infected vines have the potential to spread the virus over time. GLRaV-3 spread by $\mathrm{Pl}$. citri or Pseudococcus maritimus at low vector population density was reported with a 35 to $97.5 \%$ and a 23 to $66 \%$ increase of infected vines over 8 and 5 years, respectively $(24,68)$. Natural spread of GLRaV-3 was reported in New Zealand (21), Australia $(77,78)$, South Africa (48), Spain (22), Italy (17), and the United States $(68,158)$. Other GLRaVs that spread in vineyards include

Table 1. Mealybug (Pseudococcidae) and scale insect (Coccidae) species currently reported as vectors for grapevine-infecting ampeloviruses

\begin{tabular}{|c|c|c|c|}
\hline Virus & Mealybugs & Scale insects & References \\
\hline GLRaV-1 & $\begin{array}{l}\text { Bohemian mealybug (Heliococcus bohemicus) } \\
\text { Apple mealybug (Phenacoccus aceris) } \\
\text { Obscure mealybug (Pseudococcus viburni } \\
\text { [formerly Ps. affinis]) } \\
\text { Citrophilous mealybug (Pseudococcus calceolariae) } \\
\text { Grape mealybug (Pseudococcus maritimus) } \\
\text { Comstock mealybug (Pseudococcus comstocki) }\end{array}$ & $\begin{array}{l}\text { Pulvinaria vitis } \\
\text { Parthenolecanium corni } \\
\text { Neopulvinaria innumerabilis }\end{array}$ & $\begin{array}{l}14,17,22,48,49,65 \\
66,67,73,83,93,98 \\
102,108,112,122,145 \\
147,156,158,171\end{array}$ \\
\hline GLRaV-3 & $\begin{array}{l}\text { Bohemian mealybug (Heliococcus bohemicus) } \\
\text { Vine mealybug (Planococcus ficus) } \\
\text { Citrus mealybug (Planococcus citri) } \\
\text { Longtailed mealybug (Pseudococcus longispinus) } \\
\text { Citrophilous mealybug (Pseudococcus calceolariae) } \\
\text { Grape mealybug (Pseudococcus maritimus) } \\
\text { Obscure mealybug (Pseudococcus viburni) } \\
\text { Comstock mealybug (Pseudococcus comstocki) } \\
\text { Apple mealybug (Phenacoccus aceris) }\end{array}$ & $\begin{array}{l}\text { Pulvinaria vitis } \\
\text { Neopulvinaria innumerabilis } \\
\text { Parthenolecanium corni } \\
\text { Coccus hesperidium } \\
\text { Coccus longulus, Saissetia sp. } \\
\text { Parasaissetia nigra } \\
\text { Ceroplastes rusci }\end{array}$ & \\
\hline $\begin{array}{l}\text { GLRaV }-4 \text { and its strains } \\
-5,-6 \text {, and }-9\end{array}$ & Vine mealybug (Planococcus ficus) & Ceroplastes rusci & \\
\hline
\end{tabular}


GLRaV-1 by Heliococcus bohemicus in Italy (17) and Phenacoccus aceris in France (98), and GLRaV-4 strain -9 in Australia (79).

Many factors can influence the rate of spread and the distances over which ampelovirus spread occurs over time. Differences in the species composition of mealybug and scale insect vectors in a given grapevine-growing region and their fecundity and transmission efficiency have important epidemiological consequences. It has been reported that Parthenolecanium corni, Ps. maritimus, Pseudococcus viburni, and Pl. ficus have one, two, three, and four to six generations annually, respectively $(6,37,60,76)$, and such species-specific variability in number of generations can play a significant role in the spread of ampeloviruses. Thus, a comprehensive monitoring and sampling program (60) involving diagnostic methods (42) and synthetic sex pheromones $(11,114)$ for the collection and identification of mealybug species in vineyards can lead to a better understanding of ampelovirus epidemics. Vector feeding behavior, vine-to-vine movement, presence of ampeloviruses as single or mixed infections in source grapevines, age of grapevine at which virus acquisition or inoculation occurs, and cultivar preferences can contribute additively to the field spread of ampeloviruses. Although all mealybug vector species are known to feed and thrive on the trunk, canes, leaves, and berries (37), some like Pseudococcus calceolariae and Ps. viburni in New Zealand (13) and Pl. ficus in South Africa $(37,132)$ survive on grapevine roots in the soil and transmit GLRaV-3 from remnant roots surviving in uprooted vineyards to new plantings. The rapidity with which ampeloviruses can spread is also influenced by regional environmental and landscape variables as well as vineyard management practices that can influence the survival and dispersal of mealybug vectors (37).

\section{Strategies for Management of GLD}

Since grapevine is the only natural host known for GLRaVs, no sources of resistance to GLRaVs are known in Vitis spp., and species-specific differences occur in vector transmission $(95,126,158)$, options for disease management involve a combination of preventive, cultural, sanitary, and vector control strategies. In general, preventive measures such as establishing new vineyards with planting materials derived from virus-tested stocks, cultural practices like roguing, and control of mealybug and scale insect vectors of ampeloviruses are practiced for the management of GLRaVs. The current state of knowledge of GLD management has recently been reviewed (6), and strategies commonly deployed in vineyards are briefly discussed here.

The first line of defense against GLD is a careful selection of the planting material (both rootstock and scion) when establishing a new vineyard. Planting material, irrespective of whether it is grafted or own rooted, should originate from virus-tested, clean foundation stocks. Due to a lack of curative measures to eliminate viruses from an infected grapevine in a vineyard, macroshoot tip or meristem culture is widely adopted in generating grapevines free from GLRaVs (141). In the United States, USDA-APHIS has recently established a network of clean plant centers to facilitate the production of such pathogen-tested plant materials for nurseries and growers (http://nationalcleanplantnetwork.org/). Such a coordinated approach enables the maintenance of uniform standards in producing and supplying virus-tested planting stocks benefiting nurseries and grape growers across the country. A recent study by Fuller et al. (59) highlighted the significant economic benefits from using certified virus-free planting materials for new plantings in grower vineyards. Outside the United States, a comparable approach had been adopted by the European Union, which in 2005 issued a revision of Directive 68/193/CEE for the sanitary certificate of grapevine nursery productions.

In addition to using planting material derived from virus-tested stocks, postplanting management strategies should be implemented for reducing the spread of ampeloviruses in vineyards. Roguing or removal of infected vines is one such strategy recommended to effectively slow disease spread while ensuring profitable grape production $(10,148)$. Although symptom-based roguing can be implemented in red-berried cultivars, caution should be exercised while practicing this strategy for GLD management in whiteberried cultivars, since they express no visual symptoms. Grapevines suspected of having GLD should be sampled and tested for GLRaVs followed by roguing of virus-positive plants. Roguing is successful and effective when implemented during early stages of vineyard life, even when only a limited number of vines are infected. In the case of GLRaV-2 and -7, roguing will lead to elimination of virus-infected grapevines since these two viruses are not known to be transmitted by insect vectors. In the case of ampeloviruses (GLRaV-1, -3 , and -4 and its strains), roguing ensures removal of infected vines leading to substantial reduction of infection sources for secondary spread by mealybug and scale insect vectors. In the presence of suitable vector(s), ampeloviruses can spread quickly in the absence of roguing and reach near $100 \%$ infection rates in 5 to 10 years after planting $(24,25,77)$. Roguing should be practiced annually so that infected vines can be removed soon after the appearance of visual symptoms. Since newly infected vines can take a long time (1 to 3 years) to express visible symptoms, removing asymptomatic infected vines, using sensitive diagnostic assays, will further reduce the availability of inoculum for secondary spread. As a precaution, removal of at least one adjacent vine on either side of GLD-affected vines in a given row is recommended to reduce possible risk of residual inoculum present in the vineyard. A recent study in Israel showed that roguing infected vines can significantly reduce the rate of GLD spread from 30 to $8.6 \%$ over a 7 -year period (148). Roguing was also shown to be economically viable if disease prevalence is less than $25 \%$ in Cabernet franc vineyards in New York (10). If disease prevalence is higher than $25 \%$, a full vineyard removal is recommended. Such measures not only help maintain the profitability of vineyards but also minimize collateral damage due to virus spread from heavily infected blocks to neighboring healthy plantings by resident vector populations. For roguing to be effective, vineyards should be inspected regularly between véraison and harvest, which is the optimal time period for the manifestation of disease symptoms, particularly in red-berried $V$. vinifera cultivars. In the case of whiteberried $V$. vinifera, $V$. labrusca, V. amurensis, and interspecific hybrid cultivars as well as rootstocks, distinguishing between healthy and infected vines is difficult, necessitating diagnostic assays for identifying infected vines.

After a vineyard removal, new vines can be planted following conventional vineyard establishment practices unless vectors such as the vine ( $P$ l. ficus) and obscure (Ps. viburni) mealybugs are present in the vineyard and its vicinity. If the vine and obscure mealybugs are of concern, a fallow period of at least 1 year is recommended to break the disease cycle. Since vine and obscure mealybugs can thrive on vine roots located more than $0.5 \mathrm{~m}$ deep in the soil $(13,40,132)$, fallow allows roots to decay and helps in reducing the population of viruliferous vectors prior to planting new vines. Fallowing may not be necessary in vineyards where the grape mealybug (Ps. maritimus) is the only vector present, because this mealybug species does not thrive on residual roots in the soil (37). To aid in the reduction of viruliferous vine and obscure mealybugs, systemic herbicides can be applied prior to vine removal with the goal of reducing the persistence of live tissue in the soil that can act as reservoirs of vector populations (132).

In regions infested with viruliferous mealybugs and soft scales, the careful selection of planting material, roguing, and vineyard removal may not be sufficient to achieve acceptable disease control. This is because mealybug nymphs and adult females can crawl along the vine canopy and transmit ampeloviruses over short distances. Mealybug vectors also can be dispersed by wind currents and other means such as vineyard equipment and workers moving from an infected to a healthy vineyard. Therefore, the management of mealybug and scale insect vectors may be important in the fight against GLD. Control of mealybug populations can be achieved with natural enemies (43), parasitoids $(39,41)$, and mating disruption (164) based on pheromone traps (114-116). However, 
although attractive to reduce vector populations, biological control of mealybugs is not sufficient to restrict virus spread (76). More aggressive means based on roguing in combination with sanitary measures and timely applications of insecticides $(38,132)$ are needed to restrict virus dissemination and reduce vector populations, respectively. Several chemicals are registered for mealybugs on grapevines. Among them, the systemic insecticide Movento (spirotetramat) can lower vector populations ( $>70 \%$ reduction) but may not be completely effective at reducing ampelovirus spread since mealybugs do not die immediately after exposure (feeding) and may have time to acquire and transmit viruses. Mealybug control with contact chemicals is another option, but this approach is limited because certain stages of mealybugs often live in locations protected from nonsystemic insecticides such as under bark of trunks, spurs and canes, and on roots (for the vine and obscure mealybugs). A combination of a systemic insecticide for reducing overall populations of mealybugs and a quick-acting contact insecticide targeting more exposed crawlers, which have the highest virus transmission efficiency (156), may have a better chance of vector control. Nevertheless, more research is needed to optimize the chemical control of mealybugs and scale insects as part of GLD management.

Sanitary measures should also be considered, especially in extreme situations, where GLD is widespread and mealybug and scale insect vector populations are abundant (132). A practical approach would be for field crews to visit first healthy vineyards and subsequently infected vineyards. Vineyard workers should be encouraged to change clothes before moving between infected and healthy vineyards. Furthermore, equipment dedicated to healthy vineyards or equipment sanitation prior to moving from infected to healthy vineyards should be practiced. All these hygiene measures have synergistic value in reducing the likelihood of dissemination of mealybugs and scale insects (132).

The use of cultivars and rootstocks with resistance to GLRaVs and their vectors would be an ideal alternative for combating GLD. Unfortunately, no sources of resistance are known in Vitis species $(95,126)$. Research efforts are under way to develop host resistance to viruses (99) and their vectors through biotechnological approaches. Producing and using virus-resistant (91) and/or vectorresistant grapevine rootstocks and cultivars will greatly reduce production costs and allow growers to use more environmentally friendly production techniques by relying less on chemical, cultural, and sanitary measures for reducing virus sources and controlling their vectors. While awaiting the development of leafroll-resistant cultivars, growers should continue adopting the most appropriate strategies for their vineyards to mitigate the impact of GLD.

Overall, the most efficient management strategy for containing the spread of viruses associated with GLD should be based on careful selection of certified planting material followed by postplanting management by replacing diseased vines with healthy vines in young plantings, replanting unproductive blocks, implementing sanitary practices, and judicious and targeted application of insecticides for vector control. A concerted and cooperative effort between growers in a given grapevine-growing area is likely to be more effective for successful implementation of a mix of cultural, chemical, and sanitary measures for a synergistic effect in containing the spread of GLD between vineyards. Education and outreach efforts to disseminate science-based information through a variety of communication pathways are necessary to increase awareness of the negative impacts of GLD and appreciate the benefits of using certified planting stock among the grape community and to ensure active adoption of best management practices to advance sustainability and profitability of the grape industries. This approach has been successfully implemented in South Africa (132) and can be adopted for growers' advantage in other grapevinegrowing regions.

\section{Summary}

Among the numerous virus and virus-like diseases of grapevine, GLD is one of the most economically important diseases affecting the sustainability of the grape and wine industry in the United States and in other grapevine-growing countries. GLD is a complex viral disease and produces distinct symptoms in red- and whiteberried $V$. vinifera cultivars. Despite the fact that GLD was recognized in Europe in the mid-nineteenth century and in the United States in the mid-twentieth century, our knowledge of different aspects of the disease and GLRaVs is still quite limited $(29,85,94,101,105)$. The data on genome organization of GLRaVs indicate that these viruses make up one of the most diverse and unusually complex group of viruses infecting a single agriculturally important crop species, representing a unique virus pathosystem. Future studies should focus on the molecular biology of GLRaVs (viz. development and use of infectious genomic cDNA clones in reverse genetics approaches) for studying gene functions and host-virus-vector interactions, the relative efficiency with which ampeloviruses are transmitted by different vector species, as well as the role of genetically divergent GLRaVs in the biology and epidemiology of GLD. The lack of resistance to GLRaVs in Vitis species and challenges in developing disease resistance by conventional breeding necessitates innovative strategies of disease control. A holistic, multidisciplinary team approach employing the contemporary tools of molecular biology, genomics, and cell biology is likely to help elucidate different aspects of this complex disease. In addition, research is needed to fill gaps in the knowledge of ecology and epidemiology of GLD and socio-economic analysis of disease impacts for implementing integrated crop management approaches. A combination of using certified virus-tested planting material, roguing and sanitation on a consistent basis, and adopting environmentally benign vector control measures should be encouraged to implement knowledge-based, sustainable management strategies against GLD. Strong partnerships between research and extension faculty and the grape and wine industry stakeholders should be an integral part of these endeavors to translate research knowledge for practical applications, and to deploy improved disease control strategies.

\section{Acknowledgments}

The authors thank their respective funding agencies for supporting research on different aspects of grapevine leafroll disease. The opinions expressed and conclusions arrived at are those of the authors and do not necessarily reflect the views of any funding agencies. Naidu: Washington State University's Agricultural Research Center and Extension Team-based internal competitive grants, Members of the Wine Advisory Committee of the Washington State Wine Commission, Washington State Department of Agriculture, Washington State Commission on Pesticide Registration, USDA Northwest Center for Small Fruits Research, USDA-NIFA Viticulture Consortium-West, USDA-NIFA Specialty Crop Research Initiative (Award Number 2009-51181-06027). Rowhani and Golino: American Vineyard Foundation, CDFA-Fruit Tree, Nut Tree and Grapevine improvement Advisory Board (IAB). Fuchs: USDA-APHIS National Clean Plant Network, USDA-NIFA Viticulture Consortium-East, New York State Wine and Grape Foundation, Lake Erie Regional Grape Program, Kaplan Funds, New York Specialty Crop Block Grant Program, and New York Farm Viability Institute. Martelli: The National Research Council of Italy, Rome and the University of Bari, Italy. PPNS 0659, Department of Plant Pathology, College of Agricultural, Human, and Natural Resource Sciences Agricultural Research Center Project No. WNPO 0616, Washington State University, Pullman 99164.

\section{Literature Cited}

1. Abou Ghanem-Sabanadzovic, N., Sabanadzovic, S., Uyemoto, J. K., Golino, D., and Rowhani, A. 2010. A putative new ampelovirus associated with grapevine leafroll disease. Arch. Virol. 155:1871-1876.

2. Abou Ghanem-Sabanadzovic, N. A., Sabanadzovic, S., Gugerli, P., and Rowhani, A. 2012. Genome organization, serology and phylogeny of Grapevine leafroll-associated viruses 4 and 6: Taxonomic implications. Virus Res. 163:120-128.

3. Alabi, O. J., Al Rwahnih, M., Karthikeyan, G., Poojari, S., Fuchs, M., Rowhani, A., and Naidu, R. A. 2011. Grapevine leafroll-associated virus 1 occurs as genetically diverse populations. Phytopathology 101:1446-1456.

4. Alabi, O. J., Gutha, L. R., Casassa, L. F., Harbertson, J., Mirales, M., Beaver, C. W., and Naidu, R. A. 2012. Impacts of grapevine leafroll disease on own-rooted wine grape cultivar in cool climate viticulture. Pages 170-171 
in: Proc. 17th Congr. Int. Counc. Study Virus Virus-like Dis. Grapevine (ICVG

5. Alkowni, R., Zhang, Y. P., Rowhani, A., Uyemoto, J. K., and Minafra, A. 2011. Biological, molecular, and serological studies of a novel strain of grapevine leafroll-associated virus 2. Virus Genes 43:102-110.

6. Almeida, R. P. P., Daane, K. M., Bell, V. A., Blaisdell, G. K., Cooper, M. L., Herrbach, E., and Pietersen, G. 2013. Ecology and management of grapevine leafroll disease. Front. Microbiol. 4:94.

7. Al Rwahnih, M., Daubert, S., Golino, D., and Rowhani, A. 2009. Deep sequencing analysis of RNAs from grapevine showing Syrah decline symptoms reveals a multiple virus infection that includes a novel virus. Virology 387:395-401.

8. Al Rwahnih, M., Dave, A., Anderson, M., Rowhani, A., Uyemoto, J. K., and Sudarshana, M. R. 2013. Association of a DNA virus with grapevines affected by red blotch disease in California. Phytopathology 103:10691076

9. Al Rwahnih, M., Dolja, V. V., Daubert, S., Koonin, E. V., and Rowhani, A. 2012. Genomic and biological analysis of Grapevine leafroll-associated virus 7 reveals a possible new genus within the family Closteroviridae. Virus Res. 163:302-309.

10. Atallah, S., Gomez, M., Fuchs, M., and Martinson, T. 2012. Economic impact of grapevine leafroll disease on Vitis vinifera cv. Cabernet franc in Finger Lakes vineyards of New York. Am. J. Enol. Vitic. 63:73-79.

11. Bahder, B. W., Naidu, R. A., Daane, K. M., Millar, J. G., and Walsh, D. B. 2013. Pheromone-based monitoring of Pseudococcus maritimus (Hemiptera: Pseudococcidae) populations in Concord grape vineyards. J. Econ. Entomol. 106:482-490.

12. Basso, M. F., Fajardo, T. V. M., Santos, H. P., Guerra, C. C., Ayub, R. A., and Nickel, O. 2010. Leaf physiology and enologic grape quality of virusinfected plants. Trop. Plant Pathol. 35:351-359.

13. Bell, V. A., Bonfiglioli, R. G. E., Walker, J. T. S., Lo, P. L., Mackay, J. F., and McGregor S. E. 2009. Grapevine leafroll-associated virus 3 persistence in Vitis vinifera remnant roots. J. Plant Pathol. 91:527-533.

14. Belli, G., Fortusini, A., Casati, L., Belli, L., Bianco, P. A., and Prati, S. 1994. Transmission of a grapevine leafroll associated closterovirus by the scale insect Pulvinaria vitis. Riv. di Patol. Veg. 4:105-108.

15. Bertamini, M., Muthuchelian, K., and Nedunchezhian, N. 2004. Effect of grapevine leafroll on the photosynthesis of field grown grapevine plants (Vitis vinifera L. cv. Lagrein). J. Phytopathol. 152:145-152.

16. Bertazzon, N., Borgo, M., Vanin, S., and Angelini, E. 2010. Genetic variability and pathological properties of Grapevine leafroll-associated virus 2 isolates. Eur. J. Plant Pathol. 127:185-197.

17. Bertin, S., Mannini, F., Bosco, D., Gambino, G., Cuozzo, D., and Gribaudo, I. 2009. Spread of GVA, GLRaV-1 and -3 and role of the mealybug vector Heliococcus bohemicus in a vineyard of Langhe (Northwestern Italy). Pages 279-280 in: Proc. XVI Int. Counc. Study Viruses Virus-Like Dis. Grapevine.

18. Besse, S., Bitterlin, W., and Gugerli, P. 2009. Development of an ELISA for the simultaneous detection of Grapevine leafroll associated virus 4, 5 , 6, 7, and 9. Pages 296-298 in: Proc. XVI Int. Counc. Study Viruses VirusLike Dis. Grapevine.

19. Bester, R., Jooste, A. E. C., Maree, H. J., and Burger, J. T. 2012. Real-time RT-PCR high-resolution melting curve analysis and multiplex RT-PCR to detect and differentiate grapevine leafroll-associated virus 3 variant groups I, II, III and VI. Virol. J. 9:219.

20. Bester, R., Maree, H. J., and Burger, J. T. 2012. Complete nucleotide sequence of a new strain of Grapevine leafroll-associated virus 3 in South Africa. Arch. Virol. 157:1815-1819.

21. Bonfiglioli, R., Hoskins, N., and Edwards, F. 2002. Grapevine leafroll virus type 3 spreading in New Zealand. Aust. N.Z. Grape Growers Winemakers. Feb. 2002:58-61.

22. Cabaleiro, C. 2009. Current advances in the epidemiology of grapevine leafroll disease. Pages 264-268 in: Proc. XVI Int. Counc. Study Viruses Virus-Like Dis. Grapevine.

23. Cabaleiro, C., Couceiro, C., Pereira, S., Cid, M., Barrasa, M., and Segura, A. 2008. Spatial analysis of Grapevine leafroll associated virus 3 epidemics. Eur. J. Plant Pathol. 121:121-130.

24. Cabaleiro, C., and Segura, A. 2003. Monitoring the field spread of Grapevine leafroll associated virus 3 for 12 years. Pages 216-217 in: Proc. XIV Int. Counc. Study Viruses Virus-Like Dis. Grapevine.

25. Cabaleiro, C., and Segura, A. 2006. Temporal analysis of Grapevine leafroll associated virus 3 epidemics. Eur. J. Plant Pathol. 114:441-446.

26. Cabaleiro, C., Segura, A., and Garcia-Berrios, J. J. 1999. Effects of grapevine leafroll-associated virus 3 on the physiology and must of Vitis vinifera L. cv. Albariño following contamination in the field. Am. J. Enol. Vitic. 50:40-44

27. Castellano, M. A., Abou-Ghanem, N., Choueiri, E., and Martelli, G. P. 2000. Ultrastructure of grapevine leafroll-associated virus 2 and 7 infections. J. Plant Pathol. 82:9-15.

28. Charles, J. G., Cohen, D., Walker, J. T. S., Forgie, S. A., Bell, V. A., and Breen, K. C. 2006. A review of the ecology of Grapevine leafroll associated virus type 3 (GLRaV-3). N.Z. Plant Prot. 59:330-337.

29. Chiba, M., Reed, J. C., Prokhnevsky, A. I., Chapman, E. J., Mawassi, M., Koonin, E. V., Carrington, J. C., and Dolja, V. V. 2006. Diverse suppressors of RNA silencing enhance agroinfection by a viral replicon. Virology 346:7-14

30. Chooi, K. M., Cohen, D., and Pearson, M. N. 2013. Molecular characterization of two divergent variants of Grapevine leafroll-associated virus 3 (GLRaV-3) in New Zealand. Arch Virol. 158:1597-1602.

31. Cid, M., Pereira, S., Cabaleiro, C., Faoro, F., and Segura, A. 2007. Presence of Grapevine leafrol-associated virus 3 in primary salivary glands of the mealybug vector Planococcus citri suggests a circulative transmission mechanism. Eur. J. Plant Pathol. 118:23-30.

32. Coetzee, B., Freeborough, M., Maree, H. J., Celton, J., Rees, D. J., and Burger, J. T. 2010. Deep sequencing analysis of viruses infecting grapevines: Virome of a vineyard. Virology 400:157-163.

33. Constable, F. E., Connellan, J., Nicholas, P., and Rodon, B. C. 2012. Comparison of enzyme-linked immunosorbent assays and reverse transcriptionpolymerase chain reaction for the reliable detection of Australian grapevine viruses in two climates during three growing seasons. Aust. J. Grape Wine Res. 18:239-244.

34. Constable, F. E., Connellan, J., Nicholas, P., and Rodoni, B. C. 2013. The reliability of woody indexing for detection of grapevine virus-associated diseases in three different climatic conditions in Australia. Aust. J. Grape Wine Res. 19:74-80.

35. Coombe, B. G., and McCarthy, M. G. 2000. Dynamics of grape berry growth and physiology of ripening. Aust. J. Grape Wine Res. 6:131-135.

36. Cretazzo, E., Padilla, C., Carambula, C., Hita, I., Salmerón, E., and Cifre, J. 2010. Comparison of the effects of different virus infections on performance of three Majorcan grapevine cultivars in field conditions. Ann. Appl. Biol. 156:1-12.

37. Daane, K. M., Almeida, R. P. P., Bell, V. A., Botton, M., Fallahzadeh, M., Mani, M., Miano, J. L., Sforza, R., Walton, V. M., and Zaviezo, T. 2012. Biology and management of mealybugs in vineyards. Pages 271-308 in: Arthropod Management in Vineyards. N. J. Bostanian, R. Isaacs, and C. Vincent, eds. Springer, Dordrecht, the Netherlands.

38. Daane, K. M., Bentley, W. J., Walton, V. M., Malakar-Kuenen, R., Yokota, G. Y., Millar, J. G., Ingels, C. A., Weber, E. A., and Gispert, C. 2006. Sustainable controls sought for the invasive vine mealybug. Calif. Agric. 60:31-38.

39. Daane, K. M., Cooper, M. L., Triapitsyn, S. V., Andrews, J. W., Jr., and Ripa, R. 2008. Parasitoids of obscure mealybug, Pseudococcus viburni (Signoret) (Hem. Pseudococcidae) in California vineyards: Establishment of Pseudaphycus flavidulus (Brèthes) (Hym.: Encyrtidae) and discussion of reared parasitoid species. BioControl Sci. Technol. 18:43-57.

40. Daane, K. M., Cooper, M. L., Triapitsyn, S. V., Walton, V. M., Yokota, G. Y., Haviland, D. R., Bentley, W. J., Godfrey, K. E., and Wunderlich, L. R. 2008. California vineyard managers and researchers seek sustainable solutions for mealybugs, a changing pest complex. Calif. Agric. 62:167-176.

41. Daane, K. M., Malakar-Kuenen, R., and Walton, V. M. 2004. Temperature development of Anagyrus pseudococci (Hymenoptera: Encyrtidae) as a parasitoid of the vine mealybug, Planococcus ficus (Homoptera: Pseudococcidae). Biol. Contr. 31:123-132.

42. Daane, K. M., Middleton, M. C., Sforza, R., Cooper, M. L., Walton, V. M., Walsh, D. B., Zaviezo, T., and Almeida, R. P. P. 2011. Development of a multiplex PCR for identification of vineyard mealybugs. Environ. Entomol. 40:1595-1603.

43. Daane, K. M., Sime, K. R., Fallon, J., and Cooper, M. L. 2007. Impacts of Argentine ants on mealybugs and their natural enemies in California's coastal vineyards. Ecol. Entomol. 32:583-596.

44. Dawson, W. O., Garnsey, S. M., Tatineni, S., Folimonova, S. Y., Harper, S. J., and Gowda, S. 2013. Citrus tristeza virus-host interactions. Front. Microbiol. 4:88.

45. Dolja, V. V., and Koonin, E. V. 2013. The closterovirus-derived gene expression and RNA interference vectors as tools for research and plant biotechnology. Front. Microbiol. 4:83.

46. Dolja, V. V., Kreuze, J. F., and Valkonen, J. P. T. 2006. Comparative and functional genomics of closteroviruses. Virus Res. 117:38-51.

47. Domingo, E., Martin, V., Perales, C., Grande-Perez, A., Garcia-Arriaza, J., and Arias, A. 2006. Viruses as quasispecies: Biological implications. Curr. Top Microbiol. Immunol. 299:51-82.

48. Douglas, N., and Krüger, K. 2008. Transmission efficiency of Grapevine leafroll-associated virus 3 (GLRaV-3) by the mealybug Planococcus ficus and Pseudococcus longispinus (Hemiptera: Pseudococcidae). Eur. J. Plant Pathol. 122:207-212.

49. Elbeaino, T., Numic, F., Digiaro, M., Sabanadzovic, S., and Martelli, G. P. 2009. Partial characterization of a grapevine leafroll-associated virus isolated from an infected Cypriot vine. J. Plant Pathol. 91:479-484.

50. Engel, E. A., Escobar, P. F., Rojas, L. A., Rivera, P. A., Fiore, N., and Valenzuela, P. D. 2010. A diagnostic oligonucleotide microarray for simultaneous detection of grapevine viruses. J. Virol. Methods 163:445-451.

51. Espinoza, C., Medina, C., Somerville, S., and Arce-Johnson, P. 2007. Senescence-associated genes induced during compatible viral interactions with grapevine and Arabidopsis. J. Exp. Bot. 58:3197-3212.

52. Espinoza, C., Vega, A., Medina, C., Schlauch, K., Cramer, G., and ArceJohnson, P. 2007. Gene expression associated with compatible viral diseases in grapevine cultivars. Funct. Integr. Genomics 7:95-110.

53. FAO. 2012. Food and Agriculture Organization of the United Nations 
FAOSTAT-Agriculture. Accessed on July 12, 2014 at http://faostat3.fao. org/faostat-gateway/go/to/home/E

54. Faoro, F. 1997. Cytopathology of closteroviruses and trichoviruses infecting grapevines. Pages 29-47 in: Filamentous Viruses of Woody Plants. P. L. Monette, ed. Research Signpost, Trivandrum, India.

55. Fei, F., Lyu, M. D., Li, J., Fan, Z. F., and Cheng, Y. Q. 2013. Complete nucleotide sequence of a Chinese isolate of Grapevine leafroll-associated virus 3 reveals a 5' UTR of 802 nucleotides. Virus Genes 46:182-185.

56. Forsline, P. L., Hoch, J., Limboy, W. F., McFerson, J. R., Golino, D., and Gonsalves, D. 1996. Comparative effectiveness of symptomatology and ELISA for detecting two isolates of grapevine leafroll in Cabernet Franc. Am. J. Enol. Vitic. 47:239-243.

57. Freeborough, M.-J., and Burger, J. 2006. Leaf roll: Economic implications. Wynboer. Accessed on August 16, 2013 at http://www.wynboer.co.za/ recentarticles/200812-leafroll.php3

58. Fuchs, M., Martinson, T. E., Loeb, G. M., and Hoch, H. C. 2009. Survey for the three major leafroll disease-associated viruses in Finger Lakes vineyards in New York. Plant Dis. 93:395-401.

59. Fuller, K. B., Alston, J. M., and Golino, D. A. 2013. The benefits from certified virus-free nursery stock: A case study of grapevine leafroll-3 in the North Coast region of California. Robert Mondavi Institute-Center for Wine Economics Working Paper number 1306, UC-Davis. p. 35.

60. Geiger, C. A., and Daane, K. M. 2001. Seasonal movement and distribution of the grape mealybug (Homoptera: Pseudococcidae): Developing a sampling program for San Joaquin Valley vineyards. J. Econ. Entomol. 94:291-301.

61. Giampetruzzi, A. V., Roumi, R., Roberto, U., Malossini, N., Yoshikawa, P., La Notte, P., Terlizzi, F., Credi, R., and Saldarelli, P. 2012. A new grapevine virus discovered by deep sequencing of virus- and viroid derived small RNAs in cv Pinot gris. Virus Res. 163:262-268.

62. Goheen, A. C., and Cook, J. A. 1959. Leafroll (red-leaf or rougeau) and its effects on vine growth, fruit quality, and yields. Am. J. Enol. Vitic. 10(4):173-181.

63. Goheen, A. C., Harmon, F. N., and Weinberger, J. H. 1958. Leafroll (White Emperor disease) of grapes in California. Phytopathology 48:51-54.

64. Goheen, A. C., and Hewitt, W. B. 1964. Diagnosis of leafroll of grapevines. Riv. di Pathol. Veg. 4:427-442.

65. Golino, D. A., Sim, S. T., Gill, R., and Rowhani, A. 2002. California mealybugs can spread grapevine leafroll disease. Cal. Agric. 56:196-201.

66. Golino, D. A., Sim, S., Rill, R., and Rowhani, A. 1999. Four species of California mealybugs can transmit leafroll disease. Am. J. Enol. Vitic. 50:367-368.

67. Golino, D. A., Sim, S. T., and Rowhani, A. 1995. Transmission studies of grapevine leafroll-associated virus and grapevine corky bark-associated virus by the obscure mealybug. Am. J. Enol. Vitic. 46:408.

68. Golino, D. A., Weber, E., Sim, S., and Rowhani, A. 2008. Leafroll disease is spreading rapidly in a Napa Valley vineyard. Cal. Agric. 62:156-160.

69. Golino, D. A., Wolpert, J., Sim, S. T., Benz, J., Anderson, M., and Rowhani, A. 2009. Virus effects on vine growth and fruit components of three California 'Heritage' clones of Cabernet Sauvignon. Pages 243-244 in: Proc. XVI Int. Counc. Study Viruses Virus-Like Dis. Grapevine. Dijon, France.

70. Goszczynski, D. E. 2013. Brief report of a new highly divergent variant of Grapevine leafroll-associated virus 3 (GLRaV-3). J. Phytopathol. 161:874879.

71. Goszczynski, D. E., Kasdorf, G. G. F., Pietersen, G., and van Tonder, H. 1996. Grapevine leafroll-associated virus 2 (GLRaV-2) - mechanical transmission, purification, production and properties of antisera, detection by ELISA. S. Afr. J. Enol. Vitic. 17:15-26.

72. Grasswitz, T. R., and James, D. G. 2008. Movement of grape mealybug, Pseudococcus maritimus, on and between host plants. Entomol. Exp. Appl. 129:268-275.

73. Gugerli, P. 2003. Grapevine leafroll and related viruses. Pages 25-31 in: Proc. XIV Int. Counc. Study Viruses Virus-Like Dis. Grapevine. Locorotondo (Bari), Italy.

74. Guidoni, S., Mannini, F., Ferrandino, A., Argamante, N., and Di Stefano, R. 1997. The effect of grapevine leafroll and rugose wood sanitation on agronomic performance and berry and leaf phenolic content of a Nebbiolo Clone (Vitis vinifera L.). Am. J. Enol. Vitic. 48:438-442.

75. Gutha, L. R., Casassa, L. F., Harbertson, J. F., and Naidu, R. A. 2010. Modulation of flavonoid biosynthetic pathway genes and anthocyanins due to virus infection in grapevine (Vitis vinifera L.) leaves. BMC Plant Biol. 10:187.

76. Gutierrez, A. P., Daane, K. M., Ponti, L., Walton, V. M., and Ellis, C. K. 2008. Prospective evaluation of the biological control of vine mealybug: Refuge effects and climate. J. Appl. Ecol. 45:524-536.

77. Habili, N., Fazeli, C., Ewart, A., Hamilton, R., Cirami, R., Saldarelli, P., Minafra, A., and Rezaian, M. 1995. Natural spread and molecular analysis of grapevine leafroll-associated virus 3 in Australia. Plant Dis. 85:14181422

78. Habili, N., and Nutter, F. W. 1997. Temporal and spatial analysis of grapevine leafroll-associated virus 3 in Pinot noir grapevines in Australia. Plant Dis. 81:625-628.

79. Habili, N., Randles, J. W., and Rowhani, A. 2003. Evidence for the appar- ent spread of Grapevine virus A and Grapevine leafroll-associated virus 9 in a research vineyard in Australia. Pages 213-215 in: Proc. XIV Int. Counc. Study Viruses Virus-Like Dis. Grapevine. Locorotondo (Bari), Italy.

80. Havelka, J., Shukshuk, A. H., Ghaliow, M. E., Laamari, M., Kavallieratos, N. G., Tomanović, Z., Rakhshani, E., Pons, X., and Starý, P. 2011. Review of invasive grapevine aphid, Aphis illinoisensis Shimer, and native parasitoids in the Mediterranean (Hemiptera, Aphididae; Hymenoptera, Braconidae, Aphidiinae). Arch. Biol. Sci., Belgrade 63:269-274.

81. Hewitt,W. B., Goheen, A. C., Raski, D. J., and Gooding, G. V. 1962. Studies on virus diseases of grapevine in California. Vitis 3:57-83.

82. Hoefert, L. L., and Gifford, E. M. 1967. Grapevine leafroll virus - history and anatomical effects. Hilgardia 38:403-426.

83. Hommay, G., Le Maguet, J., Komar, V., Lemaire, O., and Herrbach, E. 2009. Transmission of Grapevine leafroll-associated virus-1 and -3 (Ampelovirus) and Grapevine virus A (Vitivirus) by natural populations of soft scales and mealybugs in the north-eastern French vineyard. Pages 286-287 in: Proc. XVI Int. Counc. Study Viruses Virus-Like Dis. Grapevine. Dijon, France.

84. Jarugula, S., Alabi, O. J., Martin, R. R., and Naidu, R. A. 2010. Genetic variability of natural populations of Grapevine leafroll-associated virus-2 in Pacific Northwest vineyards. Phytopathology 100:698-707.

85. Jarugula, S., Gowda, S., Dawson, W. O., and Naidu, R. A. 2010. 3'-coterminal subgenomic RNAs and putative cis-acting elements of Grapevine leafroll-associated virus 3 reveals 'unique' features of gene expression. Virol. J. 7:180.11.

86. Jelkmann, W., Mikona, C., Turturo, C., Navarro, B., Rott, M. E., Menzel, W., Saldarelli, P., Minafra, A., and Martelli, G. P. 2012. Molecular characterization and taxonomy of Grapevine leafroll-associated virus 7. Arch. Virol. 157:359-362.

87. Karasev, A. V. 2000. Genetic diversity and evolution of Closteroviruses Annu. Rev. Phytopathol. 38:293-324.

88. Klaassen, V. A., Sim, S. T., Dangl, G. S., Osman, F., Al Rwahnih, M., Rowhani, A., and Golino, D. 2011. Vitis californica and Vitis californica $\times$ Vitis vinifera hybrids are hosts for Grapevine leafroll-associated virus-2 and -3 and Grapevine virus $A$ and B. Plant Dis. 95:657-665.

89. Komar, V., Vigne, E., Demangeat, G., Lemaire, O., and Fuchs, M. 2010. Comparative performance analysis of virus-infected Vitis vinifera cv. Savagnin rose grafted onto three rootstocks. Am. J. Enol. Vitic. 61:68-73.

90. Kovacs, L. G., Hanami, H., Fortenberry, M., and Kaps, M. L. 2001. Latent infection by leafroll agent GLRaV-3 is linked to lower fruit quality in French-American hybrid grapevines Vidal blanc and St. Vincent. Am. J. Enol. Vitic. 52:254-259.

91. Krastanova, S., Ling, K., Zhu, H., Xue, B., Burr, T., and Gonsalves, D. 2000. Development of transgenic grapevine rootstocks with genes from grapevine fanleaf virus and Grapevine leafroll associated closteroviruses 2 and 3. Acta Hortic. 528:367-372.

92. Krenz, B., Thompson, J. R., Fuchs, M., and Perry, K. L. 2012. Complete genome sequence of a new circular DNA virus from grapevine. J Virol. $86: 7715$

93. Krüger, K., and Douglas-Smit, N. 2013. Grapevine leafroll-associated virus 3 (GLRaV-3) transmission by three soft scale insect species (Hemiptera: Coccidae) with notes on their biology. Afr. Entomol. 21:1-8.

94. Kurth, E. G., Peremyslov, V. V., Prokhnevsky, A. I., Kasschau, K. D., Miller, M., Carrington, J. C., and Dolja, V. V. 2012. Virus-derived gene expression and RNA interference vector for grapevine. J. Virol. 86:60026009.

95. Laimer, M., Lemaire, O., Herrbach, E., Goldschmidt, V., Minafra, A., Bianco, P., and Wetzel. T. 2009. Resistance to viruses, phytoplasmas and their vectors in the grapevine in Europe: A review. J. Plant Pathol. 91:7-23.

96. Lee, J., Keller, K. E., Rennaker, C., and Martin, R. R. 2009. Influence of grapevine leafroll associated viruses (GLRaV-2 and -3) on the fruit composition of Oregon Vitis vinifera L. cv. Pinot noir: Free amino acids, sugars, and organic acids. Food Chem. 117:99-105.

97. Lee, J., and Martin, R. R. 2009. Influence of grapevine leafroll associated viruses (GLRaV-2 and -3) on the fruit composition of Oregon Vitis vinifera L. cv. Pinot noir: Phenolics. Food Chem. 112:889-896.

98. Le Maguet, J., Beuve, M., Herrbach, E., and Lemaire, O. 2012. Transmission of six ampeloviruses and two vitiviruses to grapevine by Phenacoccus aceris. Phytopathology 102:717-723.

99. Ling, K. S., Zhu, H. Y., Alvizo, H., Hu, J. S., Drong, R. F., Slightom, J. L. and Gonsalves, D. 1997. The coat protein gene of grapevine leafroll associated closterovirus-3: Cloning, nucleotide sequencing and expression in transgenic plants. Arch. Virol. 142:1101-1116.

100. Ling, K. S., Zhu, H. Y., Petrovic, N., and Gonsalves, D. 2001. Comparative effectiveness of ELISA and RT-PCR for detecting Grapevine leafroll-associated closterovirus-3 in field samples. Am. J. Enol. Vitic. 52:21-27.

101. Liu, Y.-P., Peremyslov, V. V., Medina, V., and Dolja, V. V. 2009. Tandem leader proteases of Grapevine leafroll-associated virus-2: Host-specific functions in the infection cycle. Virology 383:291-299.

102. Mahfoudhi, N., Digiaro, M., and Dhouibi, M. H. 2009. Transmission of grapevine leafroll viruses by Planococcus ficus (Hemiptera: Pseudococcidae) and Ceroplastes rusci (Hemiptera: Coccidae). Plant Dis. 93:9991002

103. Maliogka, V. I., Dovas, C. I., Lotos, L., Efthimiou, K., and Katis, N. I. 
2009. Complete genome analysis and immunodetection of a member of a novel virus species belonging to the genus Ampelovirus. Arch. Virol. 154:209-218.

104. Mannini, F., Mollo, A., and Credi, R. 2012. Field performance and wine quality modification in a clone of Vitis vinifera cv. Dolcetto after GLRaV-3 elimination. Am. J. Enol. Vitic. 63:144-147.

105. Maree, H. J., Almeida, R. P. P., Bester, R., Chooi, K. M., Cohen, D., Dolja, V. V., Fuchs, M. F., Golino, D. A., Jooste, A. E. C., Martelli, G. P., Naidu, R. A., Rowhani, A., Saldarelli, P., and Burger, J. T. 2013. Grapevine leafroll-associated virus 3. Front. Microbiol. 4:82. doi:10.3389/fmicb. 2013.00082

106. Martelli, G. P. 1993. Graft-transmissible diseases of grapevines: Handbook for detection and diagnosis. Food and Agriculture Organization of the United Nations in cooperation with the International Council for the Study of Viruses and Virus-Like Diseases of Grapevine. Rome.

107. Martelli, G. P. 2000. Major graft-transmissible diseases of grapevines: Nature, diagnosis, and sanitation. Pages 231-236 in: Proc. 50th Anniv. Annu. Meeting ASEV, Seattle.

108. Martelli, G. P. 2012. Grape virology highlights: 2010-2012. Pages 13-31 in: Proc. 17th Congr. Int. Counc. Study Virus Virus-like Dis. Grapevine (ICVG), Davis, California, USA.

109. Martelli, G. P. 2014. Directory of virus and virus-like diseases of the grapevine and their agents. J. Plant Pathol. 96(suppl. 1):1-136.

110. Martelli, G. P., Abou Ghanem-Sabanadzovic, N., Agranowsky, A. A., Al Rawhanih, M., Dolja, V. V., Dovas, C. I., Fuchs, M., Gugerli, P., Hu, J. S., Jelkmann, W., Katis, N., Maliogka, V. I., Melzer, M. J., Menzel, W., Minafra, A., Rott, M. E., Rowhani, A., Sabanadzovic, S., and Saldarelli, P. 2012. Taxonomic revision of the family Closteroviridae with special reference to the grapevine leafroll-associated member of the genus Ampelovirus and the putative species unassigned to the family. J. Plant Pathol. 94:7-19.

111. Martelli, G. P., Agranovsky, A. A., Bar-Joseph, M., Boscia, D., Candresse, T., Coutts, R. H., Dolja, V. V., Falk, B. W., Gonsalves, D., Jelkmann, W., Karasev, A. V., Minafra, A., Namba, S., Vetten, H. J., Wisler, G. C., and Yoshikawa, N. 2002. ICTV Study Group on closteroviruses. The family Closteroviridae revised. Arch. Virol. 147:2039-2044.

112. Martelli, G. P., Saldarelli, P., and Boscia, D. 1997. Filamentous viruses of the grapevine: Closteroviruses. Pages 1-9 in: Filamentous Viruses of Woody Plants. P. L. Monette, ed. Research Signpost, Trivandrum, India.

113. Mikona, C., and Jelkmann, W. 2010. Replication of Grapevine leafrollassociated virus 7 (GLRaV-7) by Cuscuta species and its transmission to herbaceous plants. Plant Dis. 94:471-476.

114. Millar, J. G., Daane, K. M., McElfresh, J. S., Moreira, J., Malakar-Kuenen, R., Guillen, M., and Bentley, W. J. 2002. Development and optimization of methods for using sex pheromone for monitoring the mealybug Planococcus ficus (Homoptera: Pseudococcidae) in California vineyards. J. Econ. Entomol. 95:706-714.

115. Millar, J. G., Midland, S. L., McElfresh, J. S., and Daane, K. M. 2005. (2,3,4,4-tetramethylcyclopentyl) methyl acetate, a sex pheromone from the obscure mealybug: First example of a new structural class of monoterpenes. J. Chem. Ecol. 31:2999-3005.

116. Millar, J. G., Moreira, J. A., McElfresh, J. S., Daane, K. M., and Freund, A. S. 2009. Sex pheromone of the longtailed mealybug: A new class of monoterpene structure. Organic Lett. 11:2683-2685.

117. MKF Research. 2010. The impact of wine, grapes and grape products on the American economy 2007, MKF Research LLC, St. Helena, CA. Accessed on August 16, 2013 at http://www.wineinstitute.org/files/mfk_us _econ_report07.pdf

118. Monis, J., and Bestwick, R. K. 1996. Detection and localization of grapevine leafroll associated closteroviruses in greenhouse and tissue culture grown plants. Am. J. Enol. Vitic. 47:199-205.

119. Myles, S., Boyko, A. R., Brown, P. J., Grassi, F., Owens, C. L., Aradhya, M., Prins, B., Reynolds, A., Chia, J. M., Ware, D., Bustamante, C. D., and Buckler, E. S. 2011. Genetic structure and domestication history of the grape. Proc. Natl. Acad. Sci. 108:3530-3535.

120. Naidu, R. A. 2011. Virus update: The status of Washington vineyards. WSU Viticulture and Enology Extension News, Fall 2011. pp.6-7.

121. Naidu, R. A., O'Neil, S., and Walsh, D. 2008. Grapevine leafroll disease. WSU Extension Bulletin EB2027E. Accessed on August 16, 2013.

122. Nakano, M., Nakaune, R., and Komazaki, S. 2003. Mealybug transmission of grapevine viruses in Japan. Page 218 in: Proc. XIV Int. Counc. Study Viruses Virus-Like Dis. Grapevine. Locorotondo (Bari), Italy.

123. Namba, S., Yamashita, S., Doi, Y., Yora, K, Terai, Y., and Yano, R. 1979. Grapevine leafroll virus, a possible member of closteroviruses. Ann. Phytopathol. Soc. Jpn. 45:497-502.

124. NASS. 2012. USDA National Agriculture Statistics Service. 2010 grape figures. http://usda.mannlib.cornell.edu/MannUsda/viewDocumentInfo. do?documentID $=1113$

125. Nimmo-Bell. 2006. The economic effects and financial impact of GLRaV3. A Nimmo-Bell Publication, March 2006.

126. Oliver, J. E., and Fuchs, M. 2011. Tolerance and resistance to viruses and their vectors in Vitis sp.: A virologist's perspective of the literature. Am. J. Enol. Vitic. 62:438-451.

127. Osman, F., Leutenegger, C., Golino, D., and Rowhani, A. 2007. Real-time RT-PCR (TaqMan ${ }^{\oplus}$ ) assays for the detection of grapevine leafroll associ- ated viruses 1-5 and 9. J. Virol. Methods 141:22-29.

128. Osman, F., Leutenegger, C., Golino, D., and Rowhani, A. 2008. Comparison of low-density arrays, RT-PCR and real-time TaqMan® RT-PCR in detection of grapevine viruses. J. Virol. Methods 149:292-299.

129. Osman, F., Olineka, T., Hodzic, E., Golino, D., and Rowhani, A. 2012. Comparative procedures for sample processing and quantitative PCR detection of grapevine viruses. J. Virol. Methods 179:303-310.

130. Peremyslov, V. V., Andreev, I. A., Prokhnevsky, A. I., Duncan, G. H., Taliansky, M. E., and Dolja, V. V. 2004. Complex molecular architecture of beet yellows virus particles. Proc. Natl. Acad. Sci. 101:5030-5035.

131. Petersen, C. L., and Charles, J. G. 1997. Transmission of grapevine leafroll-associated closteroviruses by Pseudococcus longispinus and $P$. calceolariae. Plant Pathol. 46:509-515.

132. Pietersen, G., Spreeth, N., Oosthuizen, T., Van Rensburg, A., Van Rensburg, M., Lottering, D., Rossouw, N., and Tooth, D. 2013. Control of grapevine leafroll disease spread at a commercial wine estate in South Africa: A case study. Am. J. Enol. Vitic. 64:296-305.

133. Poojari, S., Alabi, O. J., Fofanov, V. Y., and Naidu, R. A. 2013. A leafhopper-transmissible DNA virus with novel evolutionary lineage in the Family Geminiviridae implicated in grapevine redleaf disease by next-generation sequencing. PLoS ONE 8(6):e64194.

134. Poojari, S., Alabi, O. J., and Naidu, R. A. 2013. Molecular characterization and impacts of a strain of Grapevine leafroll-associated virus 2 causing asymptomatic infection in a wine grape cultivar. Virol. J. 10:324.

135. Poojari, S., Alabi, O. J., Okubara, P., and Naidu, R. A. 2012. Detection and discrimination of grapevine leafroll-associated viruses by real-time PCR and amplicon melting curve analysis. Pages 130-131 in: Proc. 17th Congr. Int. Counc. Study Virus Virus-like Dis. Grapevine (ICVG), Davis, California, USA.

136. Prosser, S. W., Goszezynski, D. E., and Meng, B. 2007. Molecular analysis of double-stranded RNAs reveals complex infection of grapevines with multiple viruses. Virus Res. 124:151-159.

137. Rosciglione, B., and Gugerli, P. 1989. Transmission of grapevine leafroll disease and an associated closterovirus to healthy grapevine by the mealybug Planococcus ficus Signoret. Pages 67-69 in: Proc. 9th Meeting of ICVG, Kiryat Anavim 1987.

138. Rowhani, A. 1992. Use of (ab') 2 antibody fragment in ELISA for detection of grapevine viruses. Am. J. Enol. Vitic. 43:38-40.

139. Rowhani, A., Biardi, L., Johnson, R., Saldarelli, P., Zhang, Y. P., Chin, J., and Green, M. 2000. Simplified sample preparation method and one-tube RT-PCR for grapevine viruses. Pages 82-83 in: Proc. XIII Int. Counc. Study Viruses Virus-Like Dis. Grapevine, Adelaide 2000.

140. Rowhani, A., Golino, D. A., Sim, S. T., and Al Rwahnih, M. 2012. Grapevine leafroll-assiciated viruses effects on yield, vine performance and grape quality. Pages 52-53 in: Proc. 17th Congr. Int. Counc. Study Virus Virus-like Dis. Grapevine (ICVG), Davis, California, USA.

141. Rowhani, A., Uyemoto, J. K., Golino, D. A., and Martelli, G. P. 2005 Pathogen testing and certification of Vitis and Prunus species. Annu. Rev. Phytopathol. 43:261-278.

142. Saldarelli, P., Castellano, M. A., Harrison, B. D., and Martelli, G. P. 2005 Two grapevine viruses in an ornamental Vitis species from Scotland. J. Plant Pathol. 87:76.

143. Satyanarayana, T., Gowda, S., Ayllón, M. A., and Dawson, W. O. 2004 Closterovirus bipolar virion: Evidence for initiation of assembly by minor coat protein and its restriction to the genomic RNA 5' region. Proc. Natl. Acad. Sci. 101:799-804.

144. Scheu, G. 1935. Die Rollkrankheit des Rebstockes. Der Deutsche Weinbau $14: 222-223,345-346$ and 356-358.

145. Sforza, R., Boudon-Padieu, E., and Greif, C. 2003. New mealybug species vectoring grapevine leafroll-associated viruses-1 and -3 (GLRaV-1 and -3). Eur. J. Plant Pathol. 109:975-981.

146. Sharma, A. M., Wang, J., Duffy, S., Zhang, S., Wong, M. K., Rashed, A. Cooper, M. L., Daane, K. M., and Almeida, R. P. P. 2011. Occurrence of grapevine leafroll-associated virus complex in Napa Valley. PLoS ONE 6(10): 26227.

147. Sim, S. T., Rowhani, A., Al Kowni, R., and Golino, D. A. 2003. Experimental transmission of Grapevine leafroll-associated virus 5 and 9 by longtailed mealybugs. Pages 210-212 in: Proc. XIV Int. Counc. Study Viruses Virus-Like Dis. Grapevine. Locorotondo, Italy.

148. Sokolsky, T., Cohen, Y., Zahavi, T., Sapir, G., and Sharon, R. 2013. Potential efficiency of grapevine leafroll disease management strategies using simulation and real spatio-temporal disease infection data. Aust. J. Grape Wine Res. 19:431-438.

149. Steinhauer, D. A., Domingo, E., and Holland, J. J. 1992. Lack of evidence for proofreading mechanisms associated with an RNA virus polymerase. Gene 122:281-288.

150. Syller, J. 2012. Facilitative and antagonistic interactions between plant viruses in mixed infections. Mol. Plant Pathol. 13:204-221.

151. Tanne, E., Ben-Dov, Y., and Raccah, B. 1989. Transmission of closterolike particles associated with grapevine leafroll by mealybugs (Pseudococcidae) in Israel. Pages 67-69 in: Proc. 9th Meeting ICVG, Kiryat Anavim 1987.

152. This, P., Lacombe, T., and Thomas, M. R. 2006. Historical origins and genetic diversity of wine grapes. Trends Genet. 22:511-519. 


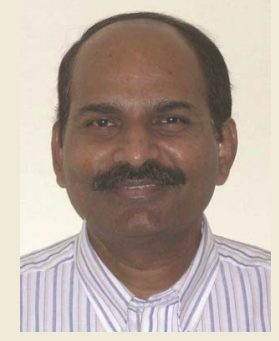

Rayapati Naidu

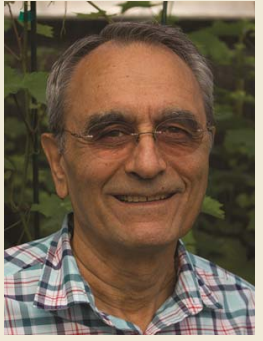

Adib Rowhani

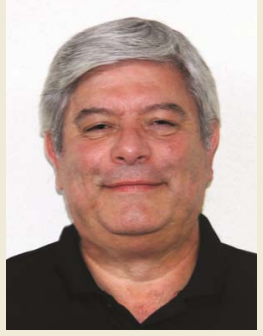

Marc Fuchs

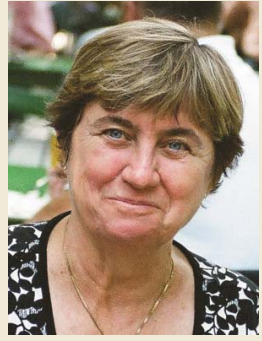

Deborah Golino

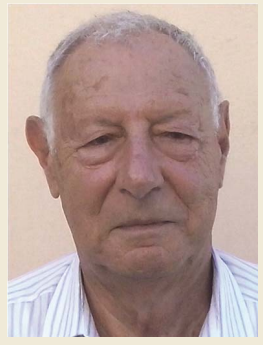

Giovanni P. Martelli
Rayapati Naidu (aka Naidu Rayapati) is associate professor of plant pathology at Washington State University's Irrigated Agriculture Research and Extension Center, Prosser. $\mathrm{He}$ is conducting fundamental and applied research on virus and virus-like diseases of grapevines. In addition, he is pursuing multidisciplinary, trans-institutional collaborative research on insect-transmitted virus diseases affecting agricultural and horticultural crops in the United States. His current international R\&D activities are focused on implementing crop improvement strategies against virus diseases in subsistence agriculture in developing countries. Naidu has established a robust extension and outreach program translating research-based knowledge into practical applications for managing virus diseases in Washington vineyards and developing countries. He teaches the course "Diseases of Fruit Crops" alternate years to provide undergraduate and graduate students a comprehensive understanding of diseases of grapevines, fruit trees, and small fruit crops. Naidu has served the American Phytopathological Society (APS) as Chair of the Virology Committee, Chair of the Plant Pathogen and Disease Detection Committee, and Associate Editor of Phytopathology, and currently serves as Section Chair - Biology of Pathogens, Annual Meeting Board of the APS. He received the International Service Award from the APS in 2007.

Dr. Rowhani is a plant virologist in the Department of Plant Pathology at the University of California, Davis. He obtained his Ph.D. in plant pathology from the University of British Columbia, Canada in 1980. His research interests are in the etiology, molecular characterization, and detection of viruses of horticultural crops with an emphasis on grapevine viruses. Dr. Rowhani also serves as a plant pathologist at Foundation Plant Services. $\mathrm{He}$ is responsible for the evaluation of the disease status of newly introduced and quarantined grapevine accessions, the inclusion of those plants in the grapevine certification program, and the assessment of the health status of foundation certified vines in the field.

Dr. Fuchs is an associate professor in the Department of Plant Pathology and Plant Microbe Biology at the Cornell University New York State Agricultural Experiment Station, and has been conducting research and extension on plant virus diseases in Geneva, NY since 2004. He received his B.S., M.S., and Ph.D. in life sciences and molecular biology from the University Louis Pasteur in Strasbourg, France. His main areas of research include diagnosis, epidemiology, resistance, and disease control. He has responsibilities in virus disease management in fruit and vegetable crops. $\mathrm{He}$ is leading a multidisciplinary team effort to determine the impact of leafroll disease and devise strategies to prevent its extension in vineyards. He is currently serving as the vice-chair of the National Clean Plant Network for grapes, director of the Northeast Plant Diagnostic Network, senior editor for Phytopathology and Journal of Plant Pathology, and associate editor for Transgenic Research.
Dr. Golino has been the director of Foundation Plant Services (FPS) since 1994. FPS is a unit of the College of Agriculture and Environmental Sciences at University of California, Davis. FPS is dedicated to the distribution of disease-tested, true-to-identity plant materials produced by UC researchers or improved by technology developed by UC researchers. At this time, FPS is responsible for programs for grapes, strawberries, fruit trees, nut trees, sweet potatoes, and roses. The grape importation, quarantine, and clean stock programs are the largest in the United States. These programs have played a key national and international role in distributing new crop varieties and healthy planting stocks. In addition to her position as FPS Director, she is a cooperative extension specialist in the Department of Plant Pathology, UC Davis, participating in teaching, extension, and service. Her research program is directed at controlling the virus and virus-like diseases of grapevines with a focus on improved methods of pathogen detection and streamlining virus elimination techniques for clean stock and quarantine programs. She is an author of more than 100 scientific publications in plant pathology.

Dr. Martelli is professor emeritus at the University of Bari, Italy, where he graduated in 1956 in agricultural sciences, later receiving the national doctorate (Libera Docenza) in plant pathology. In 1957, he joined the University of Bari, working on fungal and bacterial diseases until he moved for a postdoctoral stay at the University of California, Davis, where he was exposed to virology and nematology under the guidance of W. B. Hewitt and D. Raski, respectively. Since then, he continued virological studies aimed at the detection, characterization, epidemiology, and cytopathology of viruses responsible for diseases of grapevine, stone fruits, citrus, vegetables, and ornamentals. His contributions to grapevine virology won him the chairmanship of the International Council for the Study of Virus and Virus Diseases of the Grapevine (ICVG), which he still heads. He has contributed to the description of new virus species, genera, families, and one order, headed the Plant Virus Subcommittee of the International Committee on Taxonomy of Viruses (ICTV), served on the executive committee of ICTV, and currently is a life member. He founded and headed till retirement the Research Center on Virus Diseases of Mediterranean Crops of the National Research Council, and chaired the Department of Plant Pathology of the University of Bari. He served as president of the Italian Phytopathological Association (AFI) and of the Italian Society for Plant Pathology (SIPaV), and was a member of the executive committee of the Italian Society for Virology. $\mathrm{He}$ is the editor-in-chief of the Journal of Plant Pathology, the international journal of the SIPaV, and a member of several Italian Academies, among which is the Accademia Nazionale dei Lincei. He has been an APS member since 1963 with the status of Fellow since 1997. 
153. Thompson, J. R., Fuchs, M., Fischer, K. F., and Perry, K. L. 2012. Macroarray detection of grapevine leafroll-associated viruses. J. Virol. Methods 183:161-169.

154. Thomson, J. R., Fuchs, M., and Perry, K. L. 2012. Genomic analysis of Grapevine leafroll associated virus-5 and related viruses. Virus Res. 163:19-27.

155. Tsai, C. W., Bosco, D., Daane, K. M., and Almeida, R. P. P. 2011. Effect of host plant tissue on the vector transmission of grapevine leafroll-associated virus 3. J. Econ. Entomol. 104:1480-1485.

156. Tsai, C.-W., Chau, J., Fernandez, L., Bosco, D., Daane, K. M., and Almeida, R. R. R. 2008. Transmission of Grapevine leafroll-associated virus 3 by the vine mealybug (Planococcus ficus). Phytopathology 98:10931098.

157. Tsai, C. W., Daugherty, M. P., and Almeida, R. P. P. 2012. Seasonal dynamics and virus translocation of Grapevine leafroll-associated virus 3 in grapevine cultivars. Plant Pathol. 61:977-985.

158. Tsai, C.-W., Rowhani, A., Golino, D. A., Daane, K. M., and Almeida, R. P. P. 2010. Mealybug transmission of grapevine leafroll viruses: An analysis of virus-vector specificity. Phytopathology 100:830-834.

159. Tsitsipis, J. A., Angelakis, E., Margaritopoulos, J. T., Tsamandani, K., and Zarpas, D. 2005. First record of the grapevine aphid Aphis illinoisensis in the island of Kriti, Greece. DEPP/EPPO Bull. 35:541-542.

160. Turturo, C., Saldarelli, P., Dong, Y. F., Digiaro, M., Minafra, A., Savino, V., and Martelli, G. P. 2005. Genetic variability and population structure of Grapevine leafroll-associated virus 3 isolates. J. Gen. Virol. 86:217-224

161. Vega, A., Gutierrez, R. A., Pena-Neira, A., Cramer, G. R., and Arce-Johnson, P. 2011. Compatible GLRaV-3 viral infection affect berry ripening decreasing sugar accumulation and anthocyanin biosynthesis in Vitis vinifera. Plant Mol. Biol. 77:261-274.

162. Walker, A. R., Lee, E., Bogs, J., McDavid, D. A. J., Thomas, M. R., and
Robinson, S. P. 2007. White grapes arose through the mutation of two similar and adjacent regulatory genes. Plant J. 49:767-959.

163. Walsh, H. A., and Pietersen, G. 2013. Rapid detection of Grapevine leafroll-associated virus type 3 using a reverse transcription loop-mediated amplification. J. Virol. Methods 194:308-316.

164. Walton, V. M., Daane, K. M., Bentley, W. J., Millar, J. G., Larsen, T. E., and Malakar-Kuenen, R. 2006. Pheromone-based mating disruption of Planococcus ficus (Hemiptera: Pseudococcidae) in California vineyards. J. Econ. Entomol. 99:1280-1290.

165. Weber, E., Golino, D., and Rowhani, A. 1993. Leafroll disease of grapevines. Practical Winery and Vineyards (PWV), March/April. pp. 21-25.

166. Weber, E., Golino, D., and Rowhani, A. 2002. Laboratory testing for grapevine diseases. Practical Winery and Vineyards (PWV), January/ February. pp. 13-26.

167. Wolpert, J. A., and Vilas, E. P. 1992. Effect of mild leafroll disease on growth, yield, fruit maturity indices of Riesling and Zinfandel. Am. J. Enol. Vitic. 43:367-369.

168. Woodham, R. C., Antcliff, A. J., Krake, L. R., and Taylor, R. H. 1984. Yield differences between Sultana clones related to virus status and genetic factors. Vitis 23:73-83.

169. Zhang, Y., Singh, K., Kaur, R., and Qiu, W. 2011. Association of a novel DNA virus with the grapevine vein-clearing and vine decline syndrome. Phytopathology 101:1081-1090.

170. Zhou, C. L. E., Ammar, E.-D., Sheta, H., Kelley, S., Polek, M. L., and Ullman, D. E. 2002. Citrus tristeza virus ultrastructure and associated cytopathology in Citrus sinensis and Citrus aurantifolia. Can. J. Bot. 80:512525.

171. Zorloni, A., Prati, S., Bianco, P. A., and Belli, G. 2006. Transmission of grapevine virus $\mathrm{A}$ and Grapevine leafroll-associated virus 3 by Heliococcus bohemicus. J. Plant Pathol. 88:325-328. 